\title{
Effects of near-fault ground motions on the nonlinear behaviour of reinforced concrete framed buildings
}

\author{
Mirko Mazza
}

Received: 21 April 2015/Accepted: 19 June 2015/Published online: 17 July 2015

(C) The Author(s) 2015. This article is published with open access at Springerlink.com

\begin{abstract}
The design provisions of current seismic codes are generally not very accurate for assessing effects of near-fault ground motions on reinforced concrete (r.c.) spatial frames, because only far-fault ground motions are considered in the seismic codes. Strong near-fault earthquakes are characterized by long-duration (horizontal) pulses and high values of the ratio $\alpha_{\mathrm{PGA}}$ of the peak value of the vertical acceleration, $\mathrm{PGA}_{\mathrm{V}}$, to the analogous value of the horizontal acceleration, $\mathrm{PGA}_{\mathrm{H}}$, which can become critical for girders and columns. In this work, six- and twelve-storey r.c. spatial frames are designed according to the provisions of the Italian seismic code, considering the horizontal seismic loads acting (besides the gravity loads) alone or in combination with the vertical ones. The nonlinear seismic analysis of the test structures is performed using a step-by-step procedure based on a two-parameter implicit integration scheme and an initial stress-like iterative procedure. A lumped plasticity model based on the Haar-Kàrmàn principle is adopted to model the inelastic behaviour of the frame members. For the numerical investigation, five near-fault ground motions with high values of the acceleration ratio $\alpha_{\mathrm{PGA}}$ are considered. Moreover, following recent seismological studies, which allow the extraction of the largest (horizontal) pulse from a near-fault ground motion, five pulse-type (horizontal) ground motions are selected by comparing the original ground motion with the residual motion after the pulse has been extracted. The results of the nonlinear dynamic analysis carried out on the test structures highlighted that
\end{abstract}

M. Mazza ( $\square)$

Dipartimento di Ingegneria Civile, Università della Calabria,

Arcavacata di Rende, Ponte Bucci, Cubo 39b, Rende,

87036 Cosenza, Italy

e-mail: mirko.mazza@gmail.com horizontal and vertical components of near-fault ground motions may require additional consideration in the seismic codes.

Keywords Near-fault ground motions - Nonlinear dynamic analysis $\cdot$ r.c. spatial frames

List of symbols
$\mathrm{PGA}_{\mathrm{V}}$
$\mathrm{PGA}_{\mathrm{H}}$
$\mathrm{PGA}_{\mathrm{H}, \mathrm{FN}}$
${ }_{\mathrm{PGA}_{\mathrm{H}, \mathrm{FP}}}$
$\alpha_{\mathrm{PGA}}$
$T_{\mathrm{P}, \mathrm{FN}}$
$\Delta$
$M_{\mathrm{W}}$
$S_{\mathrm{SH}}, S_{\mathrm{SV}}$
$S_{\mathrm{T}}$
$m_{\mathrm{e}, X}, m_{\mathrm{e}, Y}, m_{\mathrm{e}, Z}$

Peak value of the vertical acceleration

Peak value of the horizontal acceleration

Peak ground acceleration for the fault-normal horizontal component Peak ground acceleration for the fault-parallel horizontal components Ratio between the peak value $\mathrm{PGA}_{\mathrm{V}}$ and $\mathrm{PGA}_{\mathrm{H}}$

Vibration period in the fault-normal direction

Closest distance to fault rupture

Moment magnitude

Subsoil parameters in the horizontal and vertical directions

Topographic parameter

Effective modal masses along directions $X, Y, Z$ defined as

percentage of total mass $m_{\mathrm{t}}$ of structure

$T_{X}, T_{Y}, T_{Z}$

Vibration periods along the directions $X, Y, Z$ corresponding to the effective modal masses

$m_{\mathrm{e}, X}, m_{\mathrm{e}, Y}, m_{\mathrm{e}, Z}$

$F_{\mathrm{H}}, F_{\mathrm{V}}$

Maximum horizontal and vertical spectral acceleration on rock site 


\begin{tabular}{|c|c|}
\hline$T_{\mathrm{r}}$ & $\begin{array}{l}\text { Return period corresponding to a } \\
\text { nominal life of the structure equal to } \\
50 \text { years }\end{array}$ \\
\hline$T_{\mathrm{C}}^{*}$ & $\begin{array}{l}\text { Upper limit of the period of the } \\
\text { constant spectral acceleration branch } \\
\text { in the horizontal direction }\end{array}$ \\
\hline$V_{\mathrm{u}}, V_{\mathrm{d}}$ & Ultimate and design shear strengths \\
\hline$N_{\mathrm{tu}}$ & Ultimate tensile force \\
\hline$N_{\mathrm{cu}}$ & Ultimate compressive force \\
\hline$N_{\mathrm{b}}$ & Balanced load \\
\hline$q_{\mathrm{H}}, q_{\mathrm{V}}$ & $\begin{array}{l}\text { Behaviour factors for the horizontal } \\
\text { seismic loads and for the vertical } \\
\text { seismic loads }\end{array}$ \\
\hline$\alpha$ & $\begin{array}{l}\text { Orientation angle of the horizontal } \\
\text { ground motion accelerations }\end{array}$ \\
\hline $\mathrm{B} 6 \mathrm{H}$ and $\mathrm{B} 12 \mathrm{H}$ & $\begin{array}{l}\text { Six- and twelve-storey r.c. framed } \\
\text { buildings designed only } \\
\text { for the horizontal seismic loads }\end{array}$ \\
\hline $\mathrm{B} 6 \mathrm{HV}$ and $\mathrm{B} 12 \mathrm{HV}$ & $\begin{array}{l}\text { Six- and twelve-storey r.c. framed } \\
\text { buildings designed for the horizontal } \\
\text { seismic loads acting in combination } \\
\text { with the vertical ones }\end{array}$ \\
\hline
\end{tabular}

\section{Introduction}

Structural damage to buildings and bridges, designed according to recent seismic codes and built within a few kilometres of a fault rupture zone, has been observed during strong near-fault ground motions (Papazoglou and Elnashai 1996; Kim and Elnashai 2008). Strong near-fault ground motions are characterized by a forward directivity effect, generating long-duration horizontal pulses, and high values of the ratio $\alpha_{\mathrm{PGA}}\left(=\mathrm{PGA}_{\mathrm{V}} / \mathrm{PGA}_{\mathrm{H}}\right)$ of the peak value of the vertical acceleration, $\mathrm{PGA}_{V}$, to the analogous value of the horizontal acceleration, $\mathrm{PGA}_{\mathrm{H}}$ (Anderson and Bertero 1987; Li and Xie 2007). Moreover, the vertical to horizontal response spectral ratios are dependent on the structural vibration period and site-to-fault distance (MacRae et al. 2001; Bozorgnia and Campbell 2004; Elnashai and Papazoglou 1997). Different techniques aimed at enhancing the seismic performance of a structure through base isolation (Mazza 2015a; Mazza et al. 2012; Mazza and Vulcano 2009; Ponzo et al. 2012) or energy dissipation (Baratta et al. 2012; Sorace and Terenzi 2014; Mazza 2015b; Mazza et al. 2015; Mazza and Vulcano 2011, 2013, 2014a, b, c) systems are available in literature to mitigate near-fault effects.

The pulse-type nature of a horizontal near-fault ground motion can make unexpected ductility demands at the end sections of both girders and columns of reinforced concrete (Liao et al. 2001) and steel (Hall et al. 1995; Tirca et al. 2003), framed structures, depending on the ratio of the pulse period to the fundamental vibration period of the structure (Alavi and Krawinkler 2004). The effect of vertical component of strong near-fault ground motions is a subject in debate since it is difficult to find the direct evidence of damage from vertical motions (Kunnath et al. 2008). A energy dissipation delay to vertical inelastic response that of the horizontal one is speculated. Besides, increasing of the acceleration ratio can notably change the axial load in reinforced concrete (r.c.) columns, producing undesirable variations in these elements (Mazza and Vulcano 2009; Mazza and Mazza 2010): e.g., reduction in the shear force, buckling of the longitudinal bars, brittle failure under compression, bond deterioration or failure under tension. Plastic hinges are needed along the span of the girders, especially if the span is rather long (Perea and Esteva 2004) and at the upper storeys (Mazza et al. 2012) where the effects of gravity loads generally are more than those of the horizontal seismic loads and an amplification of the vertical motion can be found. Particular attention was paid to studying the effects of the vertical component of near-fault ground motions on the nonlinear response of r.c. plane framed structures, taking into account infill panels (Decanini et al. 2002), masses distribution along the girders (Alaghebandian et al. 2000) and axial force-bending moment and their interaction for the columns (Mazza and Mazza 2010).

At present, the Italian (NTC08 2008) and European (Eurocode 8 2003) seismic codes do not give guidelines to taking into account jointly the effects of the horizontal and vertical components of near-fault ground motions in the design of a framed structure. In order to check the effectiveness of current code provisions and establish an additional code guidelines if it needed, it is very important to study the nonlinear response of r.c. spatial frames subjected to near-fault ground motions. In this paper, six- and twelvestorey r.c. spatial framed structures, designed with reference to NTC08, are investigated considering only horizontal seismic loads and in combination with vertical loads, respectively. Horizontal and vertical accelerograms, representative of near-fault ground motions with different values of the acceleration ratio $\alpha_{\mathrm{PGA}}$, are considered for the numerical investigation. Following recent seismological studies (Baker 2007; Chioccarelli and Iervolino 2010) which allow the extraction of the largest (horizontal) pulse from a near-fault ground motion, the corresponding farfault ground motion is represented by the residual motion

Many nonlinear three-dimensional models of r.c. frame members have been proposed in literatures. Massive calculation needed by accurate result using by finite elements or fibre models has encouraged the development of simplified approaches. In the present work, a lumped plasticity model (LPM) recently proposed (Mazza 2014a, b, c; Mazza and Mazza 2010), including axial load-biaxial 
bending moment interaction, is adopted. This is a good choice for the response simulation of structural members, like columns, that may experience inelastic deformations at the end sections, but it is not computationally efficient in the case of potential plastic hinges located at several sections along the span, requiring a sub-discretization of the frame member. More specifically, the effects of the vertical component of near-fault ground motions are expected to be evident for the girders, at the quarter-span sections, where a change in the plastic moment at the bottom side is generally assumed according to the arrangement of the longitudinal reinforcement, and at the mid-span sections, especially at the upper floors where bending moments due to vertical seismic loads are more important than those of the horizontal seismic loads. In the present work, an improvement of the above mentioned LPM is proposed in order to take into account the potential plastic hinges along the span of the girders due to the vertical ground motion, assuming a single element discretization of the structural member. To this end, the elastic domain of the end sections is modified depending on the top and bottom plastic moments of other selected critical intermediate sections (i.e. quarter- and mid-span sections). Moreover, according to the Haar-Kàrmàn principle, the elastic solution at the end sections of the frame member takes into account the inelastic effects occurring at the intermediate sections.

\section{Layout and design of the structures}

Typical six- and twelve-storey residential buildings with r.c. framed structures, whose symmetric plan is shown in Fig. 1, are considered as test structures. Deep girders are placed along the perimeter of the building together with infilled walls assumed as non-structural elements regularly distributed in elevation; deep and flat girders, perpendicular and parallel to the floor slab direction, respectively, are assumed inside the building.

Geometric dimensions of the six- and twelve-storey buildings are shown in plan and elevation, respectively, in Fig. 1a, b, while the sizes of the sections for girders and columns are shown in Table 1. Moreover, the main dynamic properties of the six- and twelve-storey buildings are also reported in Table 2: the nine vibration periods corresponding to the three highest participation modes with prevailing components in the horizontal $\left(T_{X}\right.$ or $\left.T_{Y}\right)$ or vertical $\left(T_{Z}\right)$ directions, and the corresponding effective modal masses (i.e. $m_{\mathrm{e}, X}, m_{\mathrm{e}, Y}$ and $m_{\mathrm{e}, Z}$ ) expressed as a percentage of the total mass $\left(m_{t}\right)$ of the structure.

It is worth noting that the potential critical intermediate sections of a girder, corresponding to the quarter-span and mid-span sections, are considered in order to take into
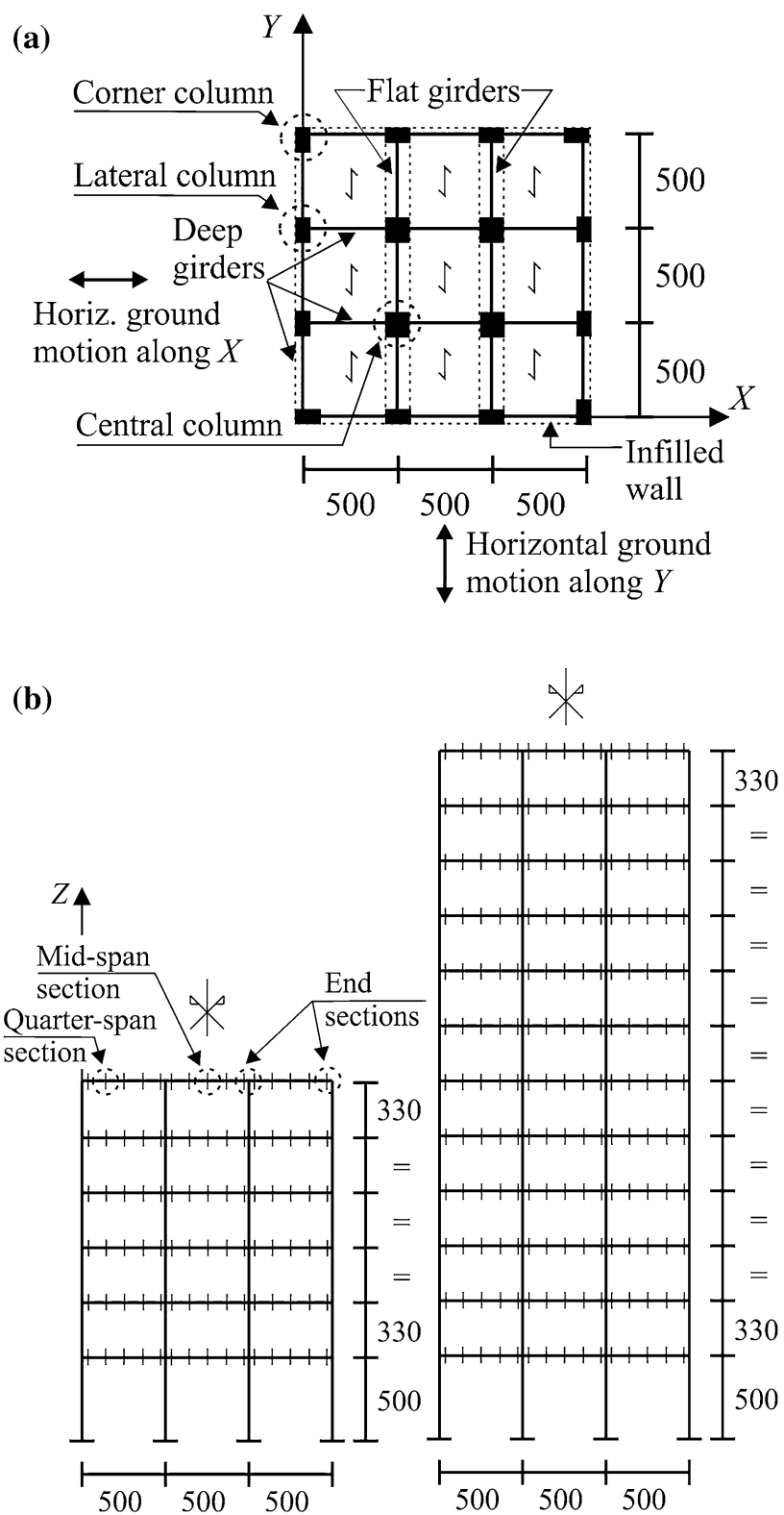

Fig. 1 R.c. test structures (dimensions in $\mathrm{cm}$ ). a Plan of the buildings. b Six- and twelve-storey frames

account the plastic deformations along the girders (Fig. 1b).

The proportioning of the test structures has been done according to the Italian seismic code (NTC08 2008) assuming, besides the gravity loads, the horizontal seismic loads acting alone or in combination with the vertical ones. Each building $(B)$ is identified by two symbols: the first one (6 or 12) indicates the number of storeys, the second one refers to the design seismic loads which are considered (i.e. $\mathrm{H}$, when considering only the horizontal component of the seismic loads; HV, when also considering the vertical component of the seismic loads). The design of the B6HV 
Table 1 Section dimensions (in $\mathrm{cm}$ ) of the six- (in brackets) and twelve-storey r.c. buildings

\begin{tabular}{llllll}
\hline Storey & Corner columns & Lateral columns & Central columns & Deep girders & Flat girders \\
\hline 12 & $30 \times 30$ & $30 \times 40$ & $40 \times 40$ & $30 \times 50$ & $50 \times 25$ \\
11 & $30 \times 30$ & $30 \times 40$ & $40 \times 40$ & $30 \times 50$ & $50 \times 25$ \\
10 & $30 \times 40$ & $30 \times 50$ & $40 \times 40$ & $40 \times 50$ & $60 \times 25$ \\
9 & $30 \times 40$ & $30 \times 50$ & $50 \times 50$ & $30 \times 60$ & $60 \times 25$ \\
8 & $35 \times 40$ & $35 \times 60$ & $50 \times 50$ & $30 \times 60$ & $70 \times 25$ \\
7 & $35 \times 40$ & $45 \times 60(30 \times 50)$ & $60 \times 60(40 \times 40)$ & $40 \times 65(30 \times 50)$ & $80 \times 25(50 \times 25)$ \\
6 & $40 \times 50(30 \times 50)$ & $45 \times 60(30 \times 50)$ & $60 \times 60(40 \times 40)$ & $40 \times 65(30 \times 50)$ & $80 \times 25(50 \times 25)$ \\
5 & $40 \times 50(30 \times 50)$ & $50 \times 70(40 \times 60)$ & $70 \times 70(50 \times 50)$ & $40 \times 65(30 \times 60)$ & $90 \times 25(60 \times 25)$ \\
4 & $50 \times 60(30 \times 60)$ & $50 \times 70(40 \times 60)$ & $70 \times 70(50 \times 50)$ & $40 \times 70(30 \times 60)$ & $90 \times 25(60 \times 25)$ \\
3 & $50 \times 60(30 \times 60)$ & $50 \times 80(60 \times 60)$ & $40 \times 70(40 \times 60)$ & $100 \times 25(70 \times 25)$ \\
2 & $50 \times 70(40 \times 70)$ & $50 \times 90(50 \times 80)$ & $80 \times(40)$ & $40 \times 70(40 \times 60)$ & $100 \times 25(70 \times 25)$ \\
1 & $50 \times 70(40 \times 70)$ & $50 \times 90(50 \times 80)$ & $80 \times 80(60 \times 60)$ & $40 \times 25$ & $70 \times 6$ \\
\hline
\end{tabular}

Table 2 Dynamic properties of the six- (in brackets) and twelve-storey r.c. buildings

\begin{tabular}{llccc}
\hline Vibration mode & Period $(\mathrm{s})$ & $m_{\mathrm{e}, X}\left(\% m_{\mathrm{t}}\right)$ & $m_{\mathrm{e}, Y}\left(\% m_{\mathrm{t}}\right)$ & $m_{\mathrm{e}, Z}\left(\% m_{\mathrm{t}}\right)$ \\
\hline 1 & $1.249(0.698)$ & $0(0)$ & $70.00(80.70)$ & $0(0)$ \\
2 & $0.993(0.576)$ & $69.50(82.30)$ & $0(0)$ & $0(0)$ \\
3 & $0.496(0.261)$ & $0(0)$ & $17.10(13.50)$ & $0(0)$ \\
4 & $0.402(0.224)$ & $18.70(13.00)$ & $0(0)$ & $0(0)$ \\
5 & $0.294(0.145)$ & $0(0)$ & $5.90(3.90)$ & $0(0)$ \\
6 & $0.240(0.126)$ & $5.60(3.30)$ & $0(0)$ & $0(0)$ \\
7 & $0.103(0.064)$ & $0(0)$ & $0(0)$ & $64.7(38.5)$ \\
8 & $0.092(0.052)$ & $0(0)$ & $0(0)$ & $9.8(33.3)$ \\
9 & $0.043(0.051)$ & $0(0)$ & $0(0)$ & $8.6(9.4)$ \\
\hline
\end{tabular}

and B12HV structures is carried out considering the maximum value of the stresses estimated considering the combination formulae of the horizontal and vertical seismic loads adopted by NTC08. The following assumptions have been made: medium subsoil (class $B$, subsoil parameters: $S_{\mathrm{SH}}=1.13$ in the horizontal direction and $S_{\mathrm{SV}}=1$ in the vertical one); flat terrain (class T1, topographic parameter: $S_{\mathrm{T}}=1$ ) and high-risk seismic region.

The design is carried out to comply with the ultimate limit state (ULS) of life safeguard, according to the horizontal and vertical elastic response spectra whose main data are reported in Tables 3 and 4: i.e. return period $\left(T_{\mathrm{r}}\right)$ corresponding to a nominal life of the structure equal to 50 years; peak ground accelerations in the horizontal $\left(\mathrm{PGA}_{\mathrm{H}}\right)$ and vertical $\left(\mathrm{PGA}_{\mathrm{V}}\right)$ directions; amplification factors defining the maximum horizontal $\left(F_{\mathrm{H}}\right)$ and vertical $\left(F_{\mathrm{V}}\right)$ spectral acceleration on rock site; upper limit of the period of the constant spectral acceleration branch in the horizontal direction $\left(T_{\mathrm{C}}^{*}\right)$. Criteria imposed by NTC08 for the regularity in plan are always satisfied. On the other hand, six- and twelve-storey structures have to be classified as being irregular in elevation as can be observed in Figs. 2
Table 3 Main parameters of the horizontal elastic response spectra

\begin{tabular}{lclll}
\hline Limit state & $T_{\mathrm{r}}(\mathrm{a})$ & $\mathrm{PGA}_{\mathrm{H}}(\mathrm{g})$ & $F_{\mathrm{H}}$ & $T_{\mathrm{C}}^{*}(\mathrm{~s})$ \\
\hline SLS (damage) & 50 & 0.108 & 2.28 & 0.301 \\
ULS (life safeguard) & 475 & 0.312 & 2.44 & 0.370 \\
\hline
\end{tabular}

Table 4 Main parameters of the vertical elastic response spectrum

\begin{tabular}{llll}
\hline Limit state & $T_{\mathrm{r}}(\mathrm{a})$ & $\mathrm{PGA}_{\mathrm{V}}(\mathrm{g})$ & $F_{\mathrm{V}}$ \\
\hline ULS (life safeguard) & 475 & 0.276 & 1.73 \\
\hline
\end{tabular}

and 3, respectively, where variation of mass (Figs. 2a, 3a), lateral stiffness (Figs. 2b, 3b) and ratio of ultimate $\left(V_{\mathrm{u}}\right)$ to design $\left(V_{\mathrm{d}}\right)$ shear strengths (Figs. 2c, 3c, in the $X$ direction, and Figs. 2d, 3d in the $Y$ direction) are plotted along the building height.

Shear strength thresholds are waived at the top level according to NTC08. As a consequence, low ductility class is considered, assuming behaviour factor for the horizontal seismic loads, $q_{\mathrm{H}}=3.12$; behaviour factor for the vertical seismic loads, $q_{\mathrm{v}}=1.5$. Finally, the serviceability limit 

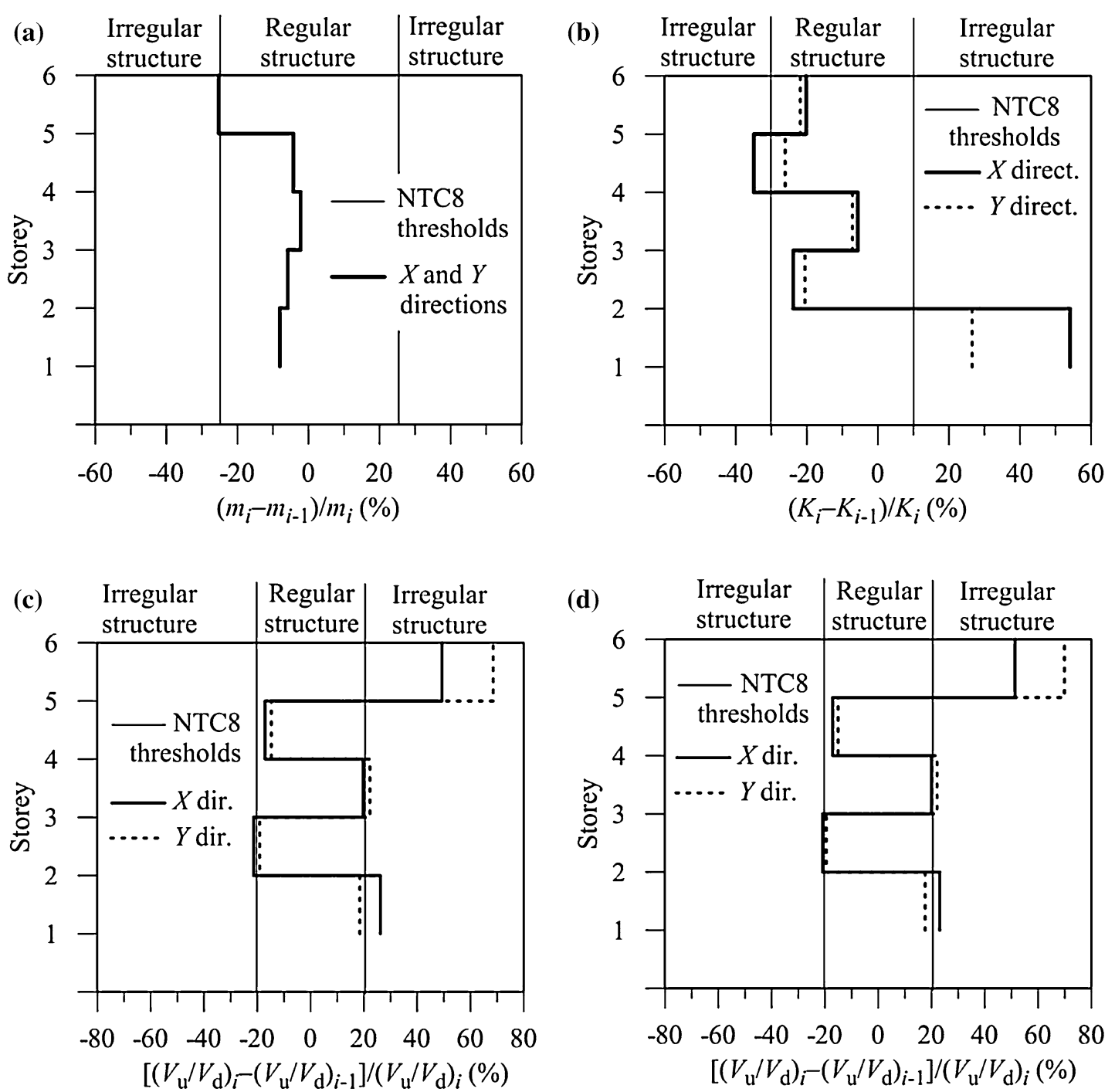

Fig. 2 Criteria for regularity in elevation of the six-storey buildings. a Mass (B6H and B6HV structures). b Lateral stiffness (B6H and B6HV structures). c Shear strength (B6H structure). d Shear strength (B6HV structure)

state (SLS) of damage is also controlled, checking that, under the horizontal seismic loads corresponding to the elastic response spectra whose main parameters are shown in Table 3, the inter-storey drift is less than $0.5 \%$ of the storey height.

The gravity loads used in the design are represented by dead- and live-loads, respectively, equal to 4.8 and $2 \mathrm{kN} /$ $\mathrm{m}^{2}$, for the top floor; 5.7 and $2 \mathrm{kN} / \mathrm{m}^{2}$, for the other floors. The weight of the perimeter masonry-infills is taken into account considering a gravity load of $2.7 \mathrm{kN} / \mathrm{m}^{2}$. A cylindrical compressive strength of $25 \mathrm{~N} / \mathrm{mm}^{2}$ for the concrete and a yield strength of $450 \mathrm{~N} / \mathrm{mm}^{2}$ for the steel are considered.

Detail for local ductility is also imposed to satisfy minimum conditions for the longitudinal bars of the r.c. frame members: for the girders a tension reinforcement ratio nowhere less than $0.3 \%$ is provided and, at their end sections, a compression reinforcement not less than half of the tension reinforcement is placed in addition to that necessary under the seismic load combination; for the section of the columns a minimum steel geometric ratio of $1 \%$ is assumed. Further rules are enforced: at least two 14-mm bars, both top and bottom, and a compression reinforcement not less than a quarter of the tension reinforcement throughout the length of the girders; for low ductility class, a maximum value of the normalized axial force in the columns less than 0.65. Finally, capacity design rules regarding the beam-column moment ratio and shear forces and local ductility requirement of girders and columns are also satisfied. 

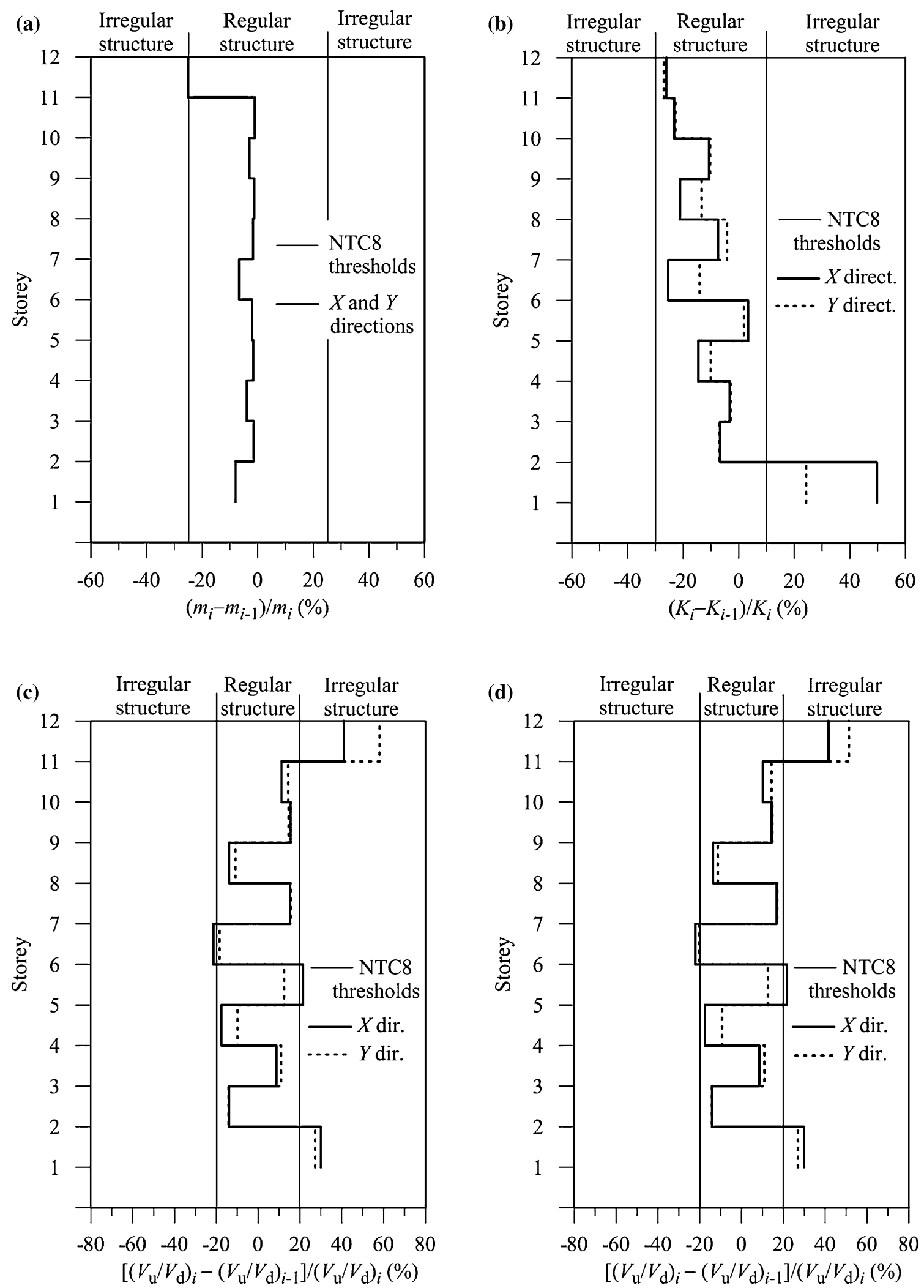

Fig. 3 Criteria for regularity in elevation of the twelve-storey buildings. a Mass (B12H and B12HV structures). b Lateral stiffness (B12H and B12HV structures). c Shear strength (B12H structure). d Shear strength (B12HV structure) 


\section{Near-fault ground motions}

The nonlinear dynamic response of the test structures described in the previous section is studied with reference to near-fault ground motions available in the Next Generation Attenuation database (2008) of the Pacific Earthquake Engineering Research center. Firstly, near-fault ground motions exhibiting high values of the acceleration ratio $\alpha_{\mathrm{PGA}}\left(=\mathrm{PGA}_{\mathrm{V}} / \mathrm{PGA}_{\mathrm{H}}\right)$ are considered for the Imperial Valley (1979), Loma Prieta (1989) and Northridge (1994) ground motions. Moreover, for the Imperial Valley ground motion, the attention is focused on the motions recorded at three different stations placed at close range to one another and exhibiting comparable $\mathrm{PGA}_{\mathrm{H}}$ values. In Table 5, the main data of the selected near-fault ground motions are reported: recording station, closest distance to fault rupture $(D)$; surface wave magnitude $\left(M_{\mathrm{S}}\right)$, peak ground acceleration for the horizontal components $\left(\mathrm{PGA}_{\mathrm{H}, 1}\right.$ and $\left.\mathrm{PGA}_{\mathrm{H}, 2}\right)$ and the vertical one $\left(\mathrm{PGA}_{\mathrm{V}}\right)$ and maximum value of the acceleration ratio (i.e. $\alpha_{\mathrm{PGA}, \max }=\mathrm{PGA}_{\mathrm{V}} / \mathrm{PGA}_{\mathrm{H} \text {,min }}$ ). It is worth noting that the acceleration ratio has a maximum value of 2.009 for the Imperial Valley ground motion, at the El Centro Differential Array (D.A.) station, as opposed to the value of 1.13 prescribed by NTC08 in the examined case. The elastic (normalized) response spectra of acceleration $\left(S_{\mathrm{a}}\right)$ are plotted in Fig. 4 , assuming an equivalent viscous damping ratio in the horizontal direction, $\xi_{\mathrm{H}}$, equal to $5 \%$, and an analogous ratio in the vertical direction, $\xi_{\mathrm{V}}$, equal to $2 \%$; the latter is due to the low damping capacity of the structure expected in the vertical direction (Papazoglou and Elnashai 1996). The response spectra of these motions are compared with the corresponding target NTC08 response spectra for a high-risk seismic region and a medium subsoil class. It is interesting to note that in the vertical direction the spectral values of acceleration (see $\mathrm{S}_{\mathrm{aV}}$ in Fig. 4c) are much greater than those corresponding to NTC08 for all the selected near-fault ground motions, at least in the range of the rather low values of the vibration periods which are more relevant for the test structures (see Table 2).

Afterwards, in order to study the effects of long-duration (horizontal) pulse-type ground motions, such as those recorded at near-fault areas, Northridge (1994), Chi-Chi
(Ji-Ji) (1999) and Kobe (1995) earthquakes have been considered. Moreover, attention has been focused on horizontal motions due to the Northridge earthquake, recorded at three stations placed at close range to one another. In Table 6, the main data of the selected near-fault ground motions are reported: recording station; closest distance to fault rupture $(\Delta)$; moment magnitude $\left(M_{\mathrm{W}}\right)$; peak ground acceleration for the fault-normal $\left(\mathrm{PGA}_{\mathrm{H}, \mathrm{FN}}\right)$ and fault-parallel $\left(\mathrm{PGA}_{\mathrm{H}, \mathrm{FP}}\right)$ horizontal components. Recent seismological studies have identified the fault-normal pulse-type records of the NGA database using a pulse indicator, which is evaluated considering the peak ground velocity $\left(\mathrm{PGV}_{\mathrm{H}, \mathrm{FN}}\right)$, also reported in Table 6 , and the record's energy (i.e. the cumulative squared velocity of the signal) of both the original ground motion and the residual motion after the pulse extraction (Baker 2007; Chioccarelli and Iervolino 2010). A wavelets-based algorithm (Baker 2007) has allowed the extraction of the largest (horizontal) pulse, having a period $T_{\mathrm{P}, \mathrm{FN}}$ in the fault-normal direction (see Table 6), from each near-fault earthquake. Curves analogous to those shown above are represented in Fig. 5, where the elastic response spectra of velocity are plotted for the original ground motion (Fig. 5a), the extracted pulse (Fig. 5b) and the residual motion (Fig. 5c) of the faultnormal component of the selected earthquakes; a thick line representing the NTC08 spectrum is also reported for a comparison. As can be observed, the response spectrum of the original ground motion of the Newhall and Rinaldi EQs is very similar to that of the corresponding extracted pulse, while for the Takarazuka EQ it is close to that of the residual ground motion.

\section{Numerical results}

A computer code was prepared according to the LPM proposed in previous works (Mazza and Vulcano 2010; Mazza and Mazza 2010; Mazza 2014a, b, c). A bilinear moment-curvature law is adopted, assuming a hardening ratio $p=5 \%$. In the Rayleigh hypothesis, the damping matrix is assumed as a linear combination of the mass and stiffness matrices, assuming a viscous damping ratio equal to $5 \%$ or $2 \%$ with reference to the two vibration periods

Table 5 Main data of the selected near-fault ground motions exhibiting high values of the acceleration ratio $\alpha_{\mathrm{PGA}}(=\mathrm{PGA} / \mathrm{PGA})$

\begin{tabular}{llllllll}
\hline Earthquake & Station & $D(\mathrm{~km})$ & $M_{\mathrm{S}}$ & PGA $_{\mathrm{H}, 1}(\mathrm{~g})$ & PGA $_{\mathrm{H}, 2}(\mathrm{~g})$ & $\mathrm{PGA}_{\mathrm{V}}(\mathrm{g})$ & $\alpha_{\mathrm{PGA}, \mathrm{max}}$ \\
\hline Imperial Valley (California), 1979-10-15 & El Centro Array \#5 & 1.0 & 6.9 & 0.379 & 0.519 & 0.537 & 1.417 \\
& El Centro Array \#7 & 0.6 & 6.9 & 0.338 & 0.463 & 0.544 & 1.609 \\
& El Centro Differential Array & 5.3 & 6.9 & 0.352 & 0.480 & 0.707 & 2.009 \\
& LGPC 16 & 6.1 & 7.1 & 0.563 & 0.605 & 0.890 & 1.581 \\
Loma Prieta (California), 1989-10-18 & Arleta & 9.2 & 6.7 & 0.308 & 0.344 & 0.552 & 1.792 \\
Northridge (California), 1994-01-17 & & &
\end{tabular}



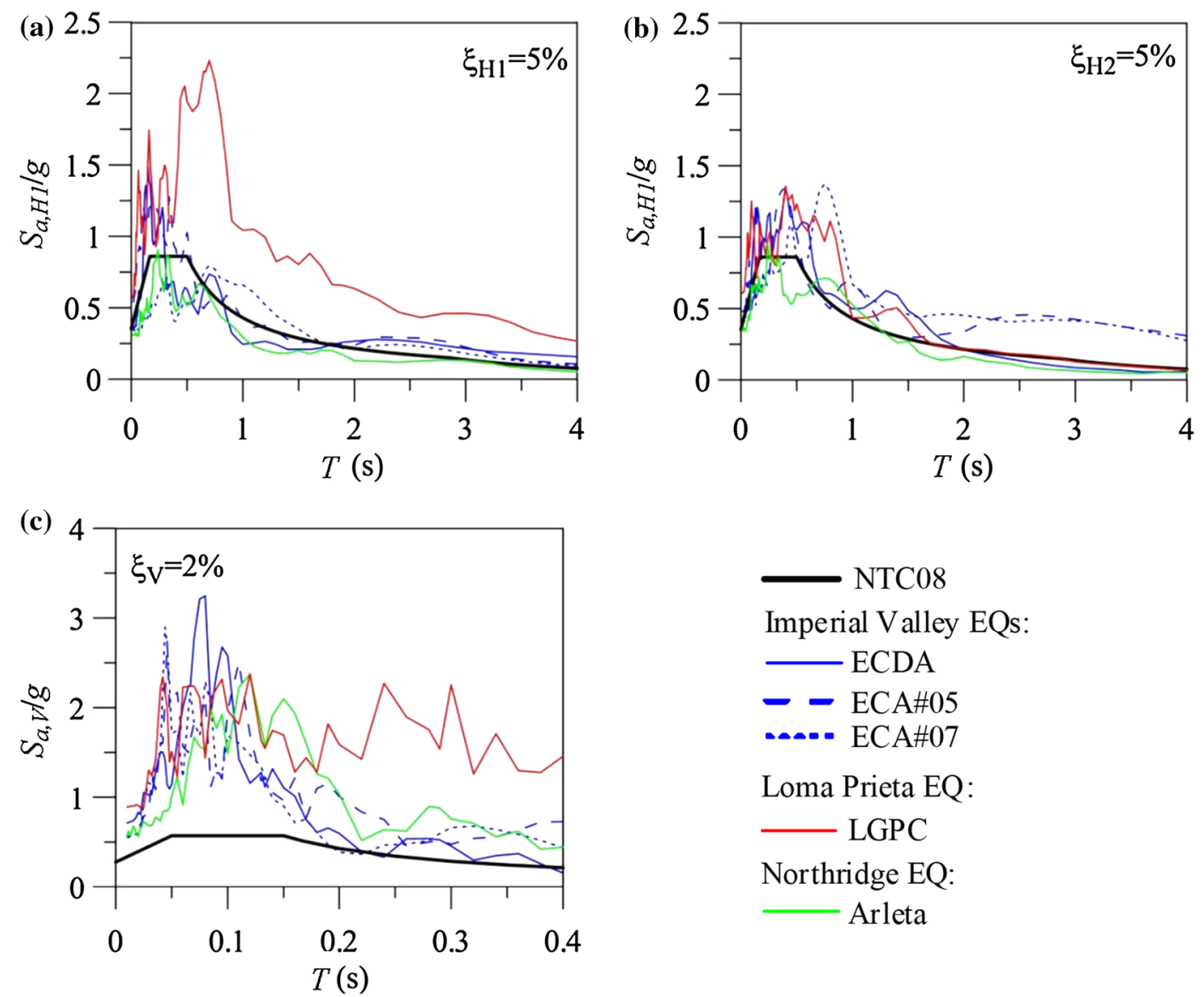

Fig. 4 Acceleration (elastic) response spectra of the selected near-fault ground motions exhibiting high values of the acceleration ratio $\alpha_{\mathrm{PGA}}$ $\left(=\mathrm{PGA}_{\mathrm{V}} / \mathrm{PGA}_{\mathrm{H}}\right)$

Table 6 Main data of the selected near-fault ground motions exhibiting pulse-type horizontal components

\begin{tabular}{|c|c|c|c|c|c|c|c|}
\hline Earthquake & Station & $\Delta$ & $M_{\mathrm{W}}$ & $\mathrm{PGA}_{\mathrm{H}, \mathrm{FN}}(\mathrm{g})$ & $\mathrm{PGA}_{\mathrm{H}, \mathrm{FP}}(\mathrm{g})$ & $\mathrm{PGV}_{\mathrm{H}, \mathrm{FN}}(\mathrm{cm} / \mathrm{s})$ & $T_{\mathrm{P}, \mathrm{FN}}(\mathrm{s})$ \\
\hline \multirow{3}{*}{$\begin{array}{l}\text { Northridge (California, US), } \\
\text { 1994-01-17 }\end{array}$} & Newhall W Pico Canyon & 5.5 & 6.7 & 0.426 & 0.279 & 87.8 & 2.4 \\
\hline & Rinaldi Receiving Station & 6.5 & 6.7 & 0.870 & 0.472 & 167.2 & 1.2 \\
\hline & Sylmar Converter Station East & 5.2 & 6.7 & 0.838 & 0.528 & 116.6 & 3.5 \\
\hline $\begin{array}{l}\text { Chi-Chi (Ji-Ji, Taiwan, China), } \\
\text { 1999-09-20 }\end{array}$ & TCU068 & 0.3 & 7.6 & 0.564 & 0.431 & 191.1 & 12.2 \\
\hline Kobe (Japan), 1995-01-16 & Takarazuka & 0.3 & 6.9 & 0.645 & 0.697 & 72.6 & 1.4 \\
\hline
\end{tabular}

corresponding to high-participation modes with components prevailing in the $Y\left(T_{1 Y}\right)$ or $Z\left(T_{1 Z}\right)$ direction, respectively. In this way, an intermediate value of the damping ratio is achieved in the range of vibration period $T_{1 Z} / T_{1 Y}$, while the higher frequency modes, which do not contribute significantly to the dynamic response, are practically eliminated due to their high damping ratio. Plastic conditions are checked at the end sections of the columns considering the effects of the axial force-biaxial bending moment interaction. Moreover, in order to emphasize the importance of also taking into account the vertical component of near-fault ground motions, three intermediate sections of control of the girders (i.e. the two quarter-span sections and the mid-span section) are checked in addition to the end sections (Fig. 1b). However, according to the model proposed in previous works, girders are discretized with only one element instead of four subelements, reducing the computational effort due to the discretization. Distributed masses are considered along the girders to evaluate the influence of the vertical vibrations adequately. The nonlinear dynamic response of the $\mathrm{B} 6 \mathrm{H}$, $\mathrm{B} 6 \mathrm{HV}, \mathrm{B} 12 \mathrm{H}$ and $\mathrm{B} 12 \mathrm{HV}$ test structures, described in Sect. 2, is studied with reference to five near-fault ground motions exhibiting high values of the acceleration ratio 

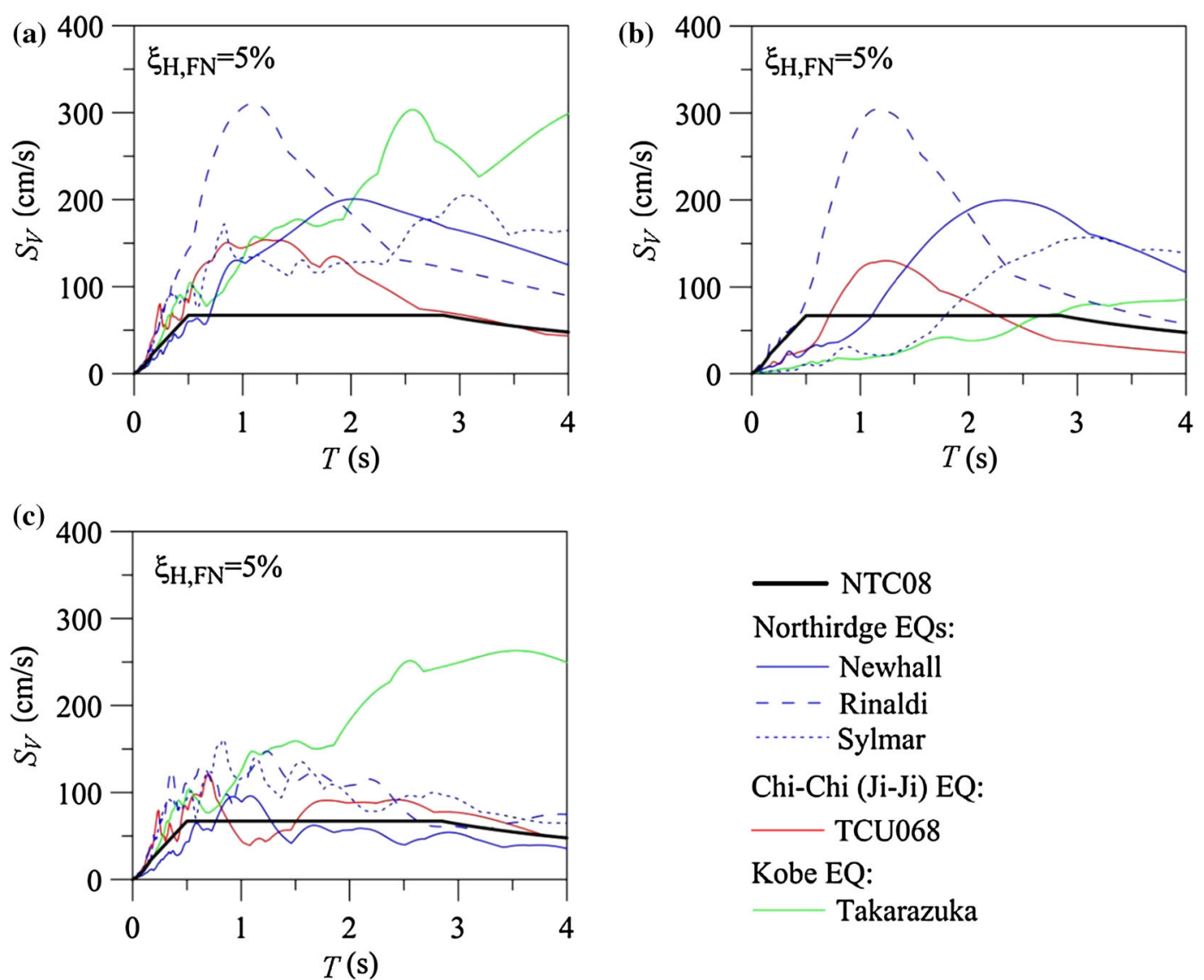

Fig. 5 Velocity (elastic) response spectra of the selected near-fault ground motions exhibiting pulse-type horizontal components (fault-normal component). a Original ground motion. b Extracted pulse. c Residual motion

$\alpha_{\mathrm{PGA}}$ (Table 5) and other five near-fault ground motions exhibiting pulse-type horizontal components (Table 6).

Information about the structural damage is obtained by referring to the curvature ductility demand calculated at each end section of the frame members. In particular, maximum values of the curvature ductility demand for the potentially critical sections of the girders (i.e. end, quarterspan and mid-span girder sections) are evaluated for each of the two loading directions.

\subsection{Effects of near-fault ground motions with high values of the acceleration ratio}

At first, to emphasize the importance of considering the vertical component of near-fault earthquakes (EQs), the attention is focused on the ductility demand of the deep girders for the B6HV (Fig. 6) and B12HV (Fig. 7) structures designed also assuming the vertical seismic loads. More specifically, maximum values are considered along the height, at the end (Figs. 6a, 7a) and quarter-span (Figs. 6b, 7b) sections, assuming that the vertical component of the selected earthquakes (see Table 5) acts contemporaneously with the horizontal components applied twice (i.e. alternatively along the principal axes $X$ and $Y$ of the building plan).

As can be observed, the end sections, at the top side, and quarter-span sections, at the bottom one, proved to be the more stressed sections for all the examined earthquakes, especially at the upper floors where the effects due to vertical seismic loads generally prevail over those of the horizontal seismic loads and an amplification of the vertical motion is expected. This kind of behaviour can be explained observing that the ductility demand at these sections, in contrast to the mid-span ones, already appears under the horizontal components of the seismic loads. Moreover, the bottom plastic moments of the quarter-span sections, at the upper floors, are less than or equal to those assumed at the mid-span sections, according to the arrangement of the longitudinal reinforcement. It should be noted that the nonlinear dynamic analyses for the B6HV and B12HV subjected to LGPC16 EQ were stopped at the time when the ultimate value of the ductility demand imposed at the end sections of the girders was exceeded.

Successively, the maximum values of the ductility demand at the end sections of the columns are evaluated with reference to the $\mathrm{B} 6 \mathrm{HV}$ and $\mathrm{B} 12 \mathrm{HV}$ structures 

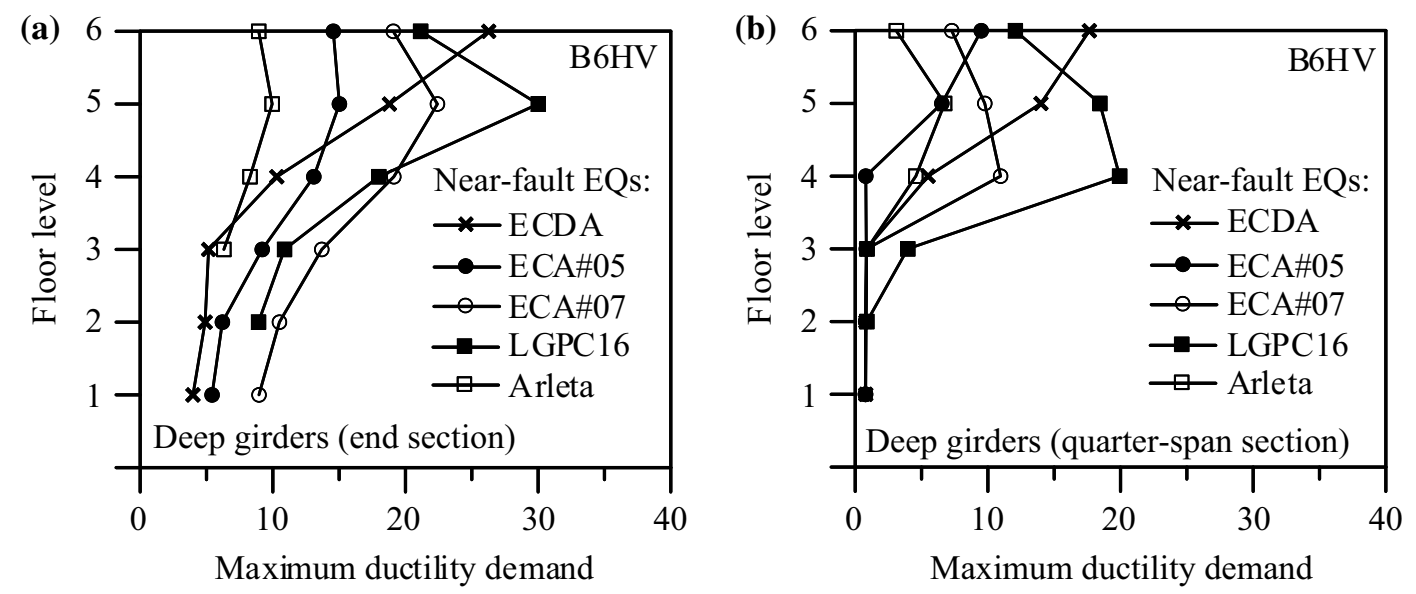

Fig. 6 Maximum ductility demand of the girders: B6HV structures subjected to near-fault motions exhibiting high values of the acceleration ratio $\alpha_{\mathrm{PGA}}$

(a)

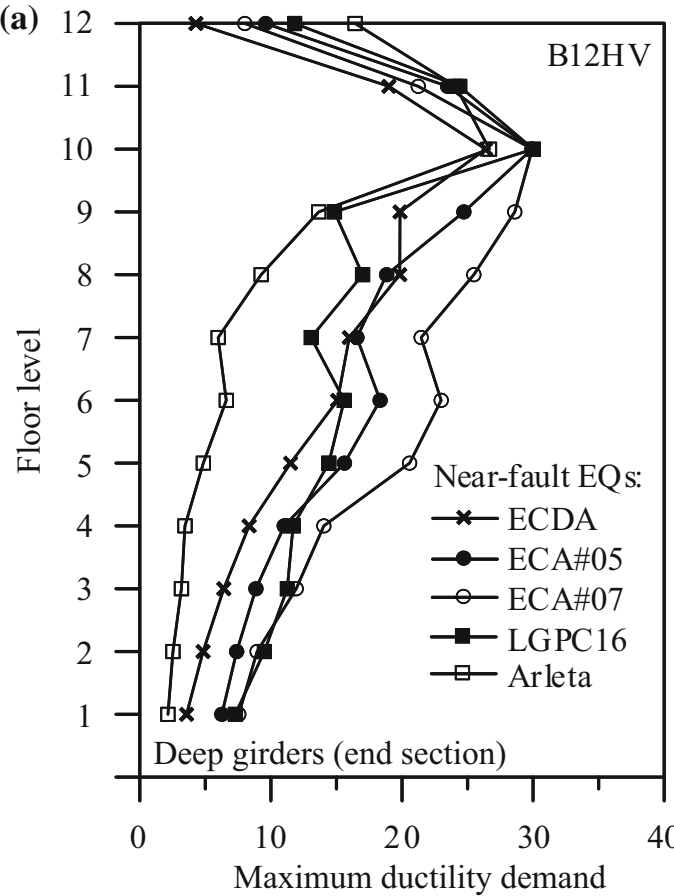

(b)

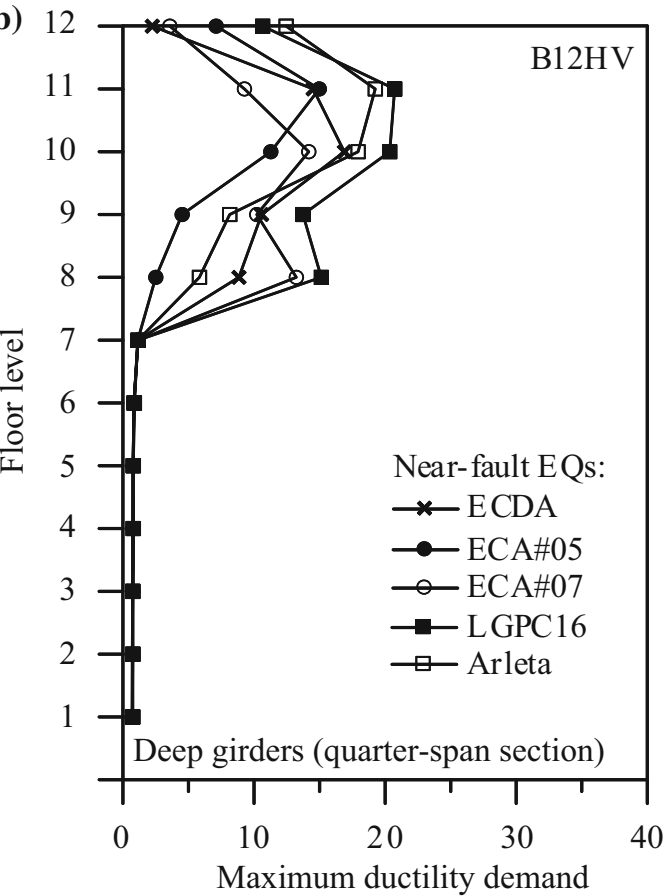

Fig. 7 Maximum ductility demand of the girders: B12HV structures subjected to near-fault motions exhibiting high values of the acceleration ratio $\alpha_{\mathrm{PGA}}$

subjected to the horizontal and vertical components of the selected earthquakes (Fig. 8). It is worth noting that the maximum ductility demand at each storey is shown for the (central, lateral or corner) column section exhibiting the maximum value, but in many cases the section where the maximum ductility value is attained is different. As can be observed, the effects of the vertical ground motion are rather low in comparison with those shown above for the girders. This is mainly due to the adoption of the capacity design rules, which are aimed at a "strong-columns weakbeams" mechanism.
In order to compare the response of the test structures designed for the horizontal seismic loads only (i.e. B6H and $\mathrm{B} 12 \mathrm{H}$ structures) with that of the analogous structures designed also for the vertical seismic loads (i.e. B6HV and B12HV structures), the curvature ductility demand of the girders, along the frame height, is reported in Fig. 9. The results refer to the horizontal components of the Imperial Valley ground motions acting alone $(\mathrm{H})$, for $\mathrm{B} 6 \mathrm{H}$ and $\mathrm{B} 12 \mathrm{H}$ structures, or contemporaneously with the corresponding vertical component $(\mathrm{H}+\mathrm{V})$, for $\mathrm{B} 6 \mathrm{HV}$ and B12HV structures. The average of the maximum (local) 

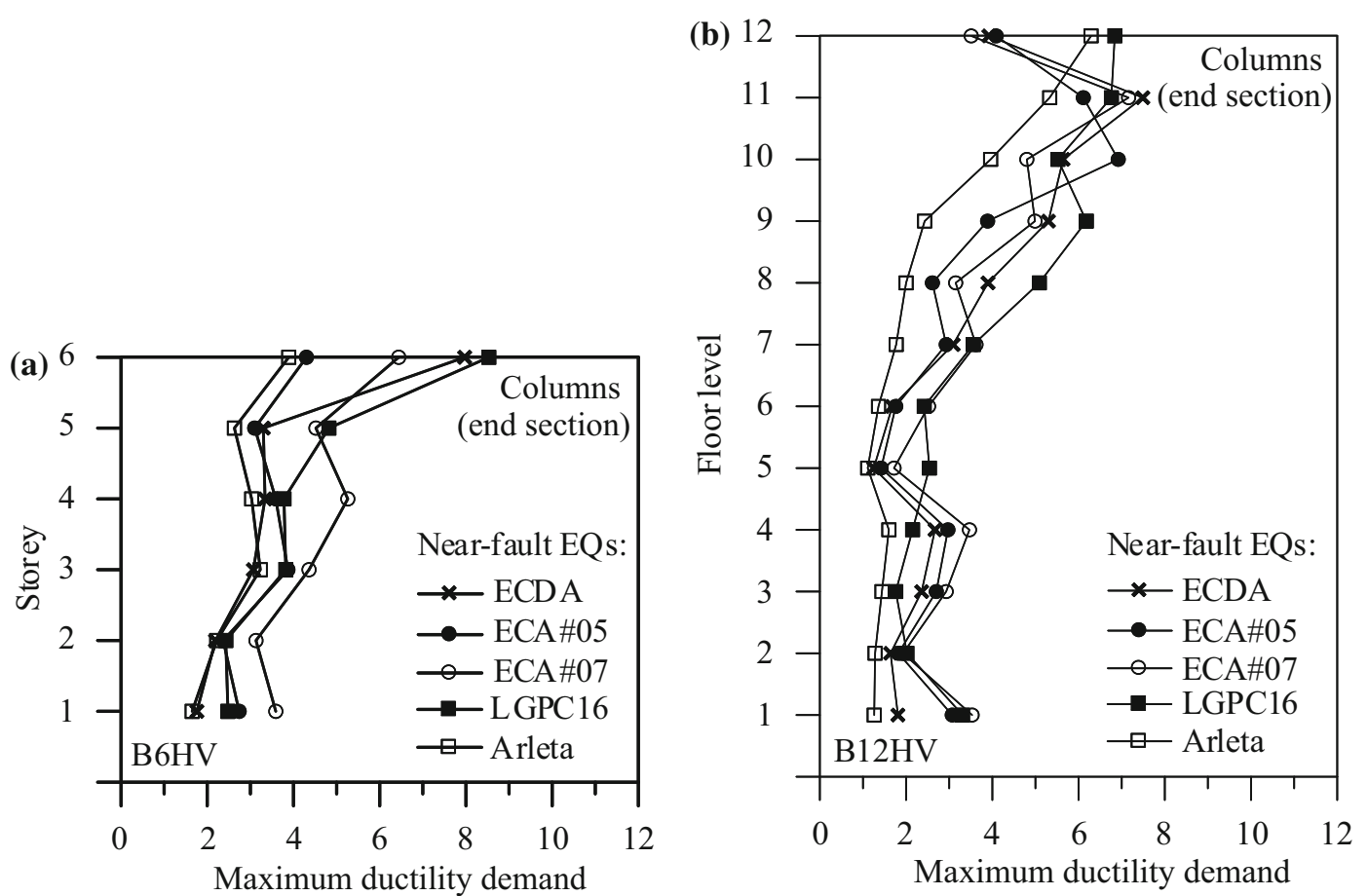

Fig. 8 Maximum ductility demand of the columns: B6HV and B12HV structures subjected to near-fault motions exhibiting high values of the acceleration ratio $\alpha_{\mathrm{PGA}}$. a $\mathrm{B} 6 \mathrm{HV}$ structure. b $\mathrm{B} 12 \mathrm{HV}$ structure
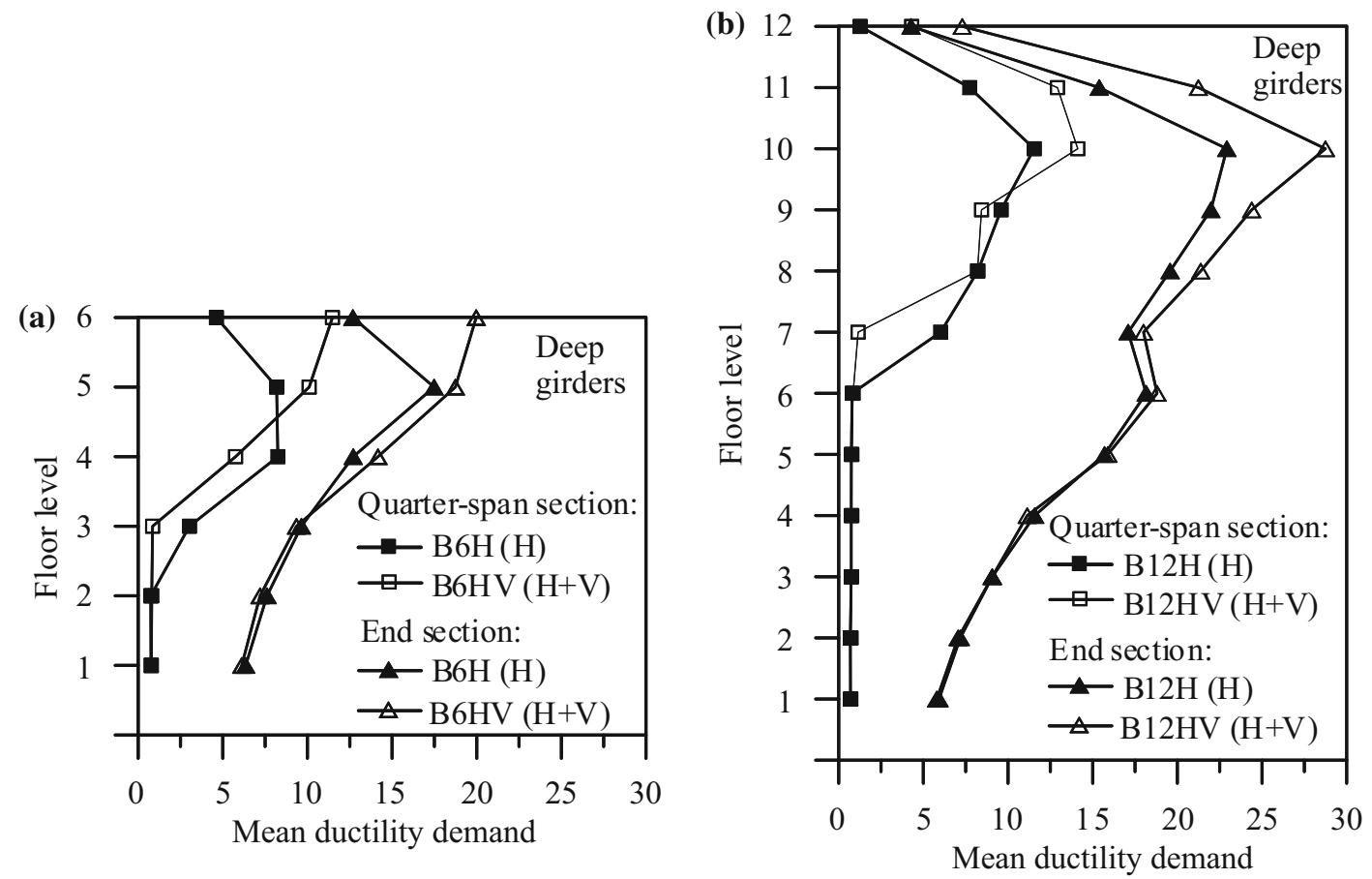

Fig. 9 Mean ductility demand of the girders for the test structures subjected to the horizontal $(\mathrm{H})$ and horizontal and vertical $(\mathrm{H}+\mathrm{V})$ components of the Imperial Valley EQs

curvature ductility demand at the end sections and quarterspan sections of the interior deep girders, perpendicular to the floor slab direction shown in Fig. 1a, is considered.
Moreover, the horizontal accelerogram with $\mathrm{PGA}_{\mathrm{H}, 1}$ $\left(\mathrm{PGA}_{\mathrm{H}, 2}\right)$ is applied twice, once along the principal axis $X(Y)$ and the other along the principal axis $Y(X)$ of the 
building plan. As shown in Fig. 9, also referring to the mean values of the ductility demand the effects of the vertical component of the Imperial Valley ground motions proved to be more evident at the upper floors. These results highlighted the need to design the central part of the girders also taking the vertical ground motion into account, especially in the upper storeys. Further results, omitted for the sake of brevity, are shown that flat girders exhibit plastic deformations at the end sections due to the horizontal components of the ground motion, but the intermediate sections are practically independent of the vertical component due to their small tributary mass, at all storeys.

Afterwards, the minimum and maximum values attained by the axial force (assuming positive compressive forces) in the central columns of $\mathrm{B} 6 \mathrm{H}$ and $\mathrm{B} 6 \mathrm{HV}$ structures subjected, respectively, to the horizontal $(\mathrm{H})$ and horizontal and vertical $(\mathrm{H}+\mathrm{V})$ components of ECDA, ECA\#5 and ECA\#7 ground motions are plotted in Fig. 10. As shown, in these columns, which have the greatest tributary mass (about twice and four times the analogous mass corresponding to a lateral column and a corner column, respectively), the addition of the vertical ground motion (Fig. 10b) produces a marked variation in the axial force which even gives rise to a tensile force, which in many cases is very close to the ultimate tensile force $\left(N_{\mathrm{tu}}\right)$. Moreover, the axial force variation induces a rather high compressive force, which in many columns is greater than the balanced load $\left(N_{\mathrm{b}}\right)$, thus producing a reduction in both the ultimate bending moment and available ductility, but less than the ultimate compressive force $\left(N_{\mathrm{cu}}\right)$. It should be noted that the balanced load has been exceeded even though, as mentioned in the previous section, the columns were designed checking also that their axial force is less than the limit prescribed by NTC 08 . It should be noted that a compressive load greater than $N_{\mathrm{b}}$ or a tensile load do not necessarily imply a brittle failure, because it depends on the value attained by the bending moment, which may be less than the ultimate moment corresponding to the current axial load.

Curves analogous to those shown above are plotted in Fig. 11 to represent the effect of the horizontal and vertical components $(\mathrm{H}+\mathrm{V})$ of the El Centro D.A. ground motion, characterized by the highest spectral values of acceleration (see Fig. 4c), among the selected Imperial valley EQs, in the range of vibration periods in the vertical direction which are more interesting for the B12HV structure (see Table 2).

As can be observed, the overturning moment due to the horizontal components also induced an evident variation in the axial load in the corner columns (Fig. 11a), which are subjected to the highest tensile force at the first storey because the effects of the vertical motion are more limited than those of the horizontal motion. On the other hand, tensile loads at the intermediate storeys are attained by the central columns (Fig. 11b).

\subsection{Effects of near-fault ground motions exhibiting pulse-type horizontal components}

To evaluate the effects of the pulse-type horizontal components of the selected near-fault ground motions (see Table 6) on the local damage undergone by deep and flat girders, the maximum ductility demand of the $\mathrm{B} 6 \mathrm{H}$ and $\mathrm{B} 12 \mathrm{H}$ structures is reported, respectively, in Figs. 12 and 13.

More specifically, the ductility demand at the end sections is evaluated considering that the fault-normal (FN) and fault-parallel (FP) horizontal components of the extracted pulses (see Sect. 3) are applied along the principal axes $X$ and $Y$ of the building plan (i.e. orientation
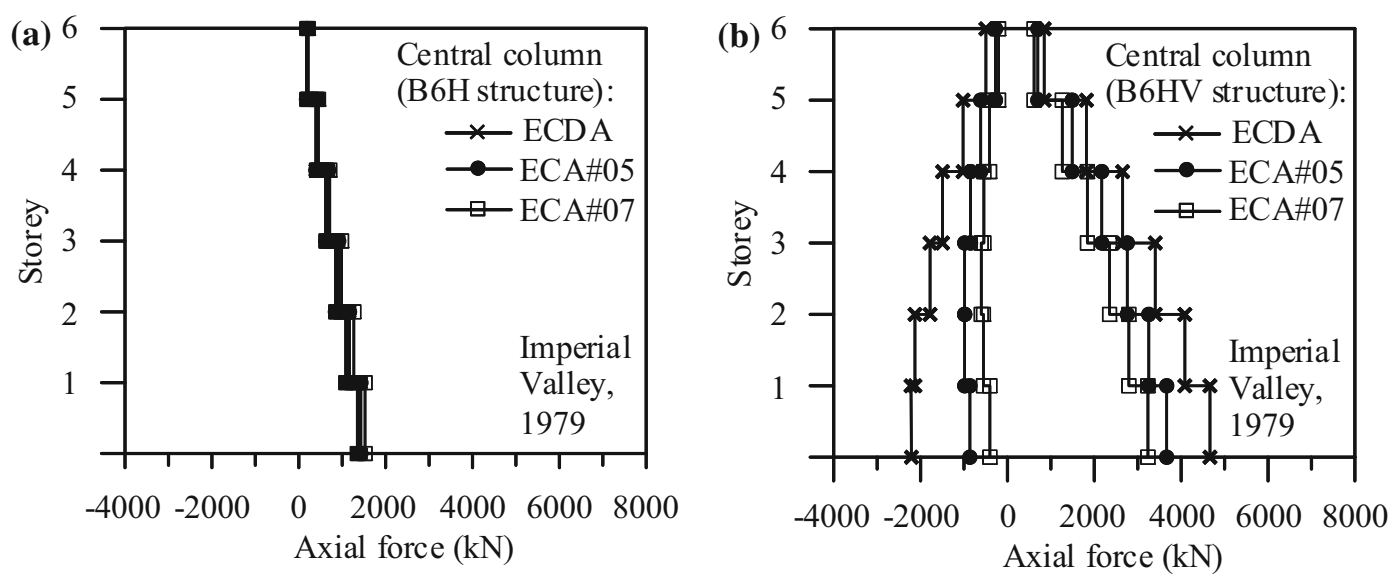

Fig. 10 Effect of the imperial valley ground motions on the minimum and maximum axial forces of the central columns of B6H and B6HV structures. a Horizontal components $(\mathrm{H})$. b Horizontal and vertical components $(\mathrm{H}+\mathrm{V})$ 

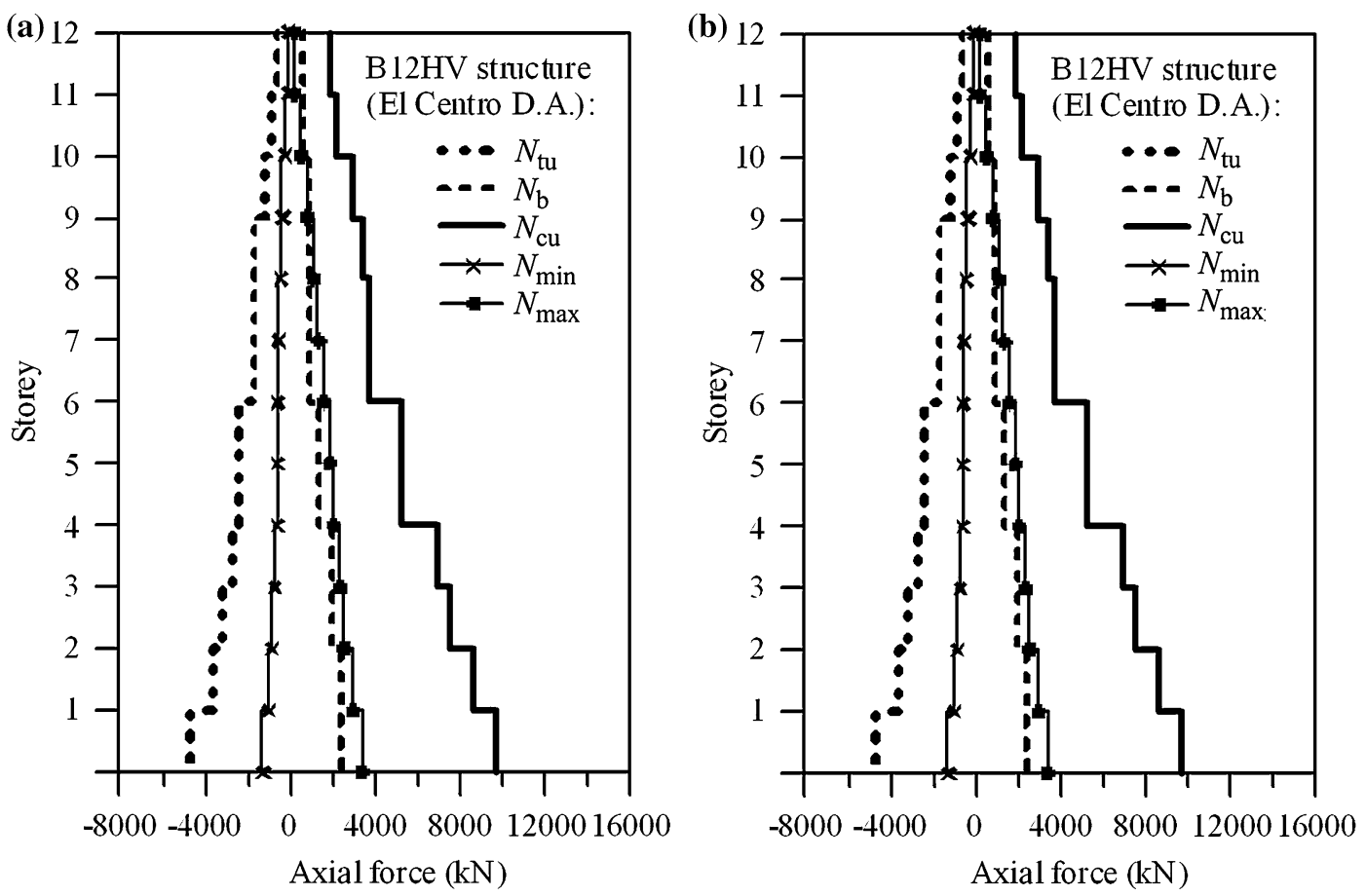

Fig. 11 Effect of the horizontal and vertical components $(\mathrm{H}+\mathrm{V})$ of the El Centro D.A. ground motion on the minimum and maximum axial forces of B12HV structure. a Corner column. b Central column
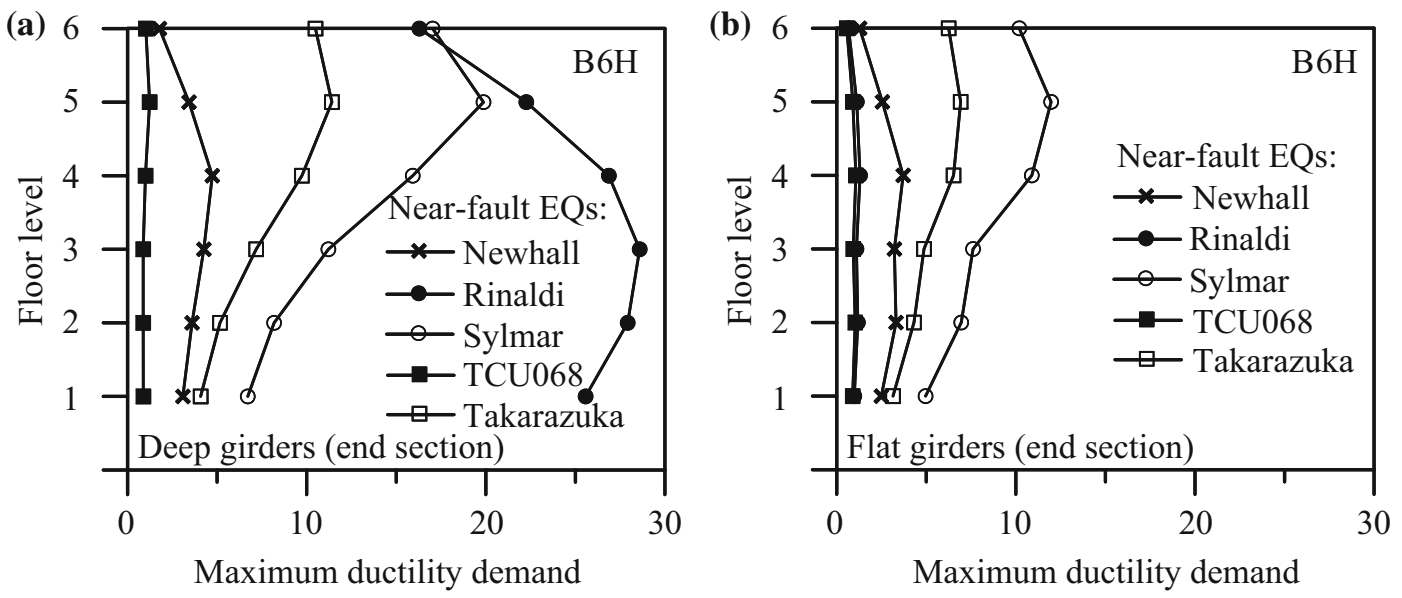

Fig. 12 Maximum ductility demand at the end section of the girders: $\mathrm{B} 6 \mathrm{H}$ structure subjected to near-fault motions exhibiting pulse-type horizontal components

angle $\alpha=0^{\circ}$ ). As can be observed, unexpected ductility demand, due to the pulse-type nature of the extracted motion, is obtained for the deep girders perpendicular to the floor slab direction (Figs. 12a, 13a). The effects of near-fault ground motions are widely variable depending on the ratio between the pulse period and the fundamental vibration periods of the structure. In particular, a comparison of the curves for the deep girders highlighted that the ductility demand for the Rinaldi EQ is greater than that obtained for the other four motions, especially at the five (seven) lower storeys of the $\mathrm{B} 6 \mathrm{H}(\mathrm{B} 12 \mathrm{H})$ structure. On the other hand, for the Chi-Chi (Ji-Ji) EQ, whose pulse period $T_{\mathrm{P}, \mathrm{FN}}$ resulted very long in comparison with the fundamental vibration periods of the test structures (see Tables 2, 6), only small ductility demands have been obtained. Finally, rather low values of ductility demand are obtained, for all the selected earthquakes, considering the flat girders (Figs. 12b, 13b), especially due to their orientation along the principal axis of the building plan which refers to the FP components. 

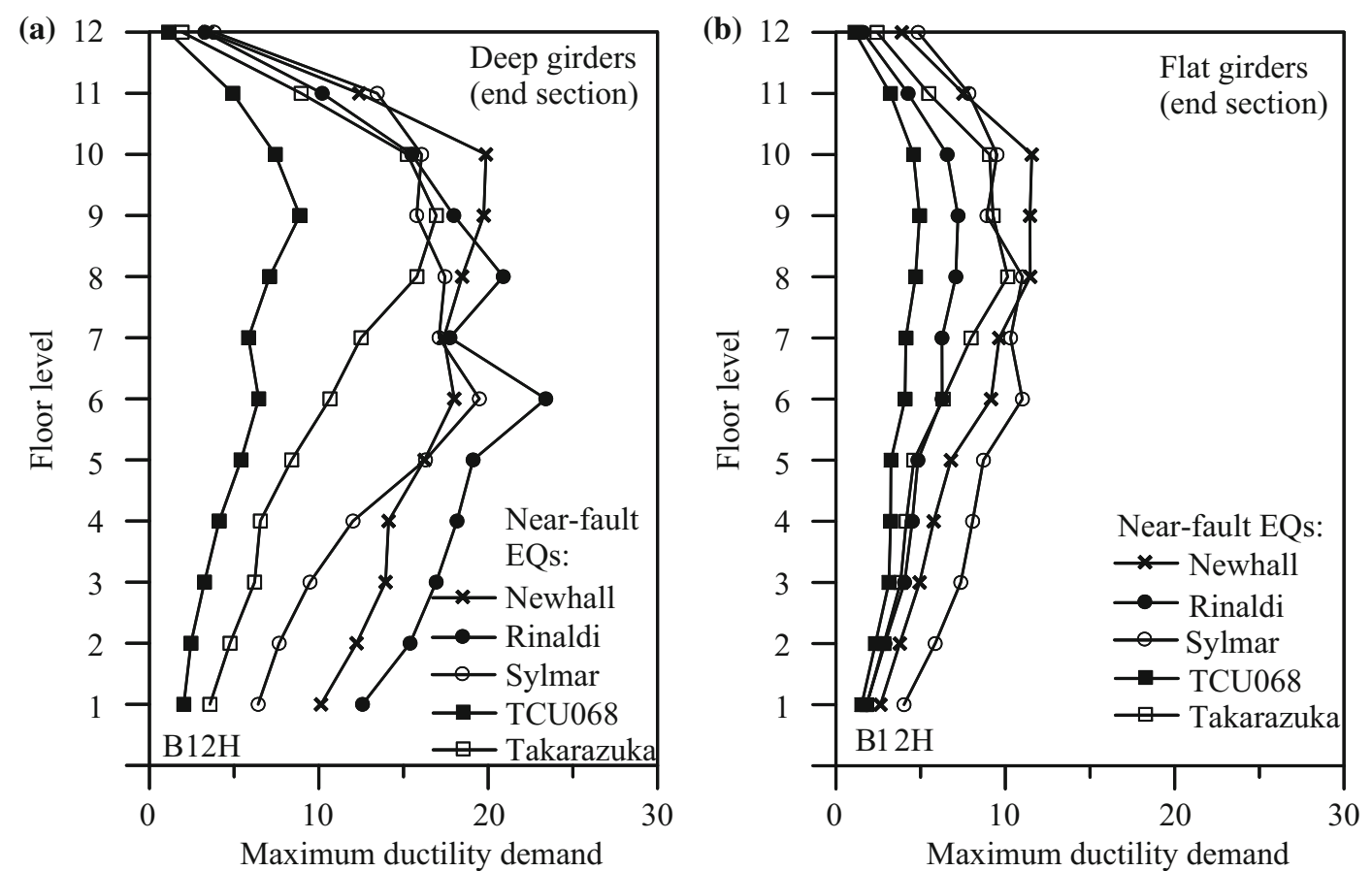

Fig. 13 Maximum ductility demand at the end section of the girders: B12H structure subjected to near-fault motions exhibiting pulse-type horizontal components

Curves analogous to those shown above are reported in Fig. 14, where the maximum ductility demand is evaluated with reference to the columns of the B6H (Fig. 14a) and B12H (Fig. 14b) structures. In the examined cases, the values of the ductility demand for the columns are rather low in comparison with those shown above for the girders; moreover, many columns exhibit an elastic behaviour. This is mainly due to the adoption of the NTC08 capacity design criterion, which is aimed to prevent the formation of a soft storey mechanism.

Finally, maximum values of ductility demand for the $\mathrm{B} 12 \mathrm{H}$ structure subjected to the extracted pulse and residual motion of the Northridge EQ (Newhall station) and the Chi-Chi (Ji-Ji) EQ (TCU068 station) are reported in Figs. 15 and 16. More specifically, ductility demand at the end sections of deep and flat girders is shown in Fig. 15, considering the FN and FP components applied along the principal axis $X$ and $Y$ of the building plan, respectively (i.e. orientation angle $\alpha=0^{\circ}$ ). It is interesting to note that the ductility demand of the girders for the extracted pulse of the Northridge EQ (Fig. 15a) proved to be, at all the storeys, greater than the corresponding values for the residual motion. This result can be explained observing that the spectral values for the residual motion are significantly smaller than those of the extracted pulse in the range of vibration periods more significant for the B12H structure (see spectral values of the extracted pulse,
Fig. 6b, and residual motion, Fig. 6c, corresponding to vibration periods greater than the fundamental periods of the B12H structure reported in Sect. 2). However, it is interesting to note an opposite trend occurred when the Chi-Chi (Ji-Ji) EQ is considered (Fig. 15b), because the period of the FN extracted pulse (i.e. $T_{\mathrm{P}, \mathrm{FN}}=12.2 \mathrm{~s}$ ) is very large in comparison with the fundamental vibration period of the $\mathrm{B} 12 \mathrm{H}$ structure along the principal axis $X$ (i.e. $T_{X}=1.249 \mathrm{~s}$ ). As a consequence, the damage due to the extracted pulse proved to be not always greater than that due to the original ground motion.

In Fig. 16, curves analogous to those shown in Fig. 15, but considering two orientation angles of the FN and FP horizontal components (i.e. $\alpha=0^{\circ}$ and $\alpha=30^{\circ}$ ), are reported for the columns of the $\mathrm{B} 12 \mathrm{H}$ structure subjected to Northridge and Chi-Chi (Ji-Ji) EQs. Also in this case, higher values of the column ductility demand can be observed for the extracted pulse of the Northridge EQ (Fig. 16a) and residual motion of the Chi-Chi (Ji-Ji) EQ (Fig. 16b). It should be noted that for the Chi-Chi (Ji-Ji) EQ the analyses were stopped because the ultimate ductility demand of the girders is achieved. It is interesting to note that the maximum values of the ductility demand have been obtained with reference to the extracted pulse rotated at $\alpha=30^{\circ}$. This result indicates that long-duration pulses, typically verifying in the $\mathrm{FN}$ direction, can occur at a large range of orientations. 

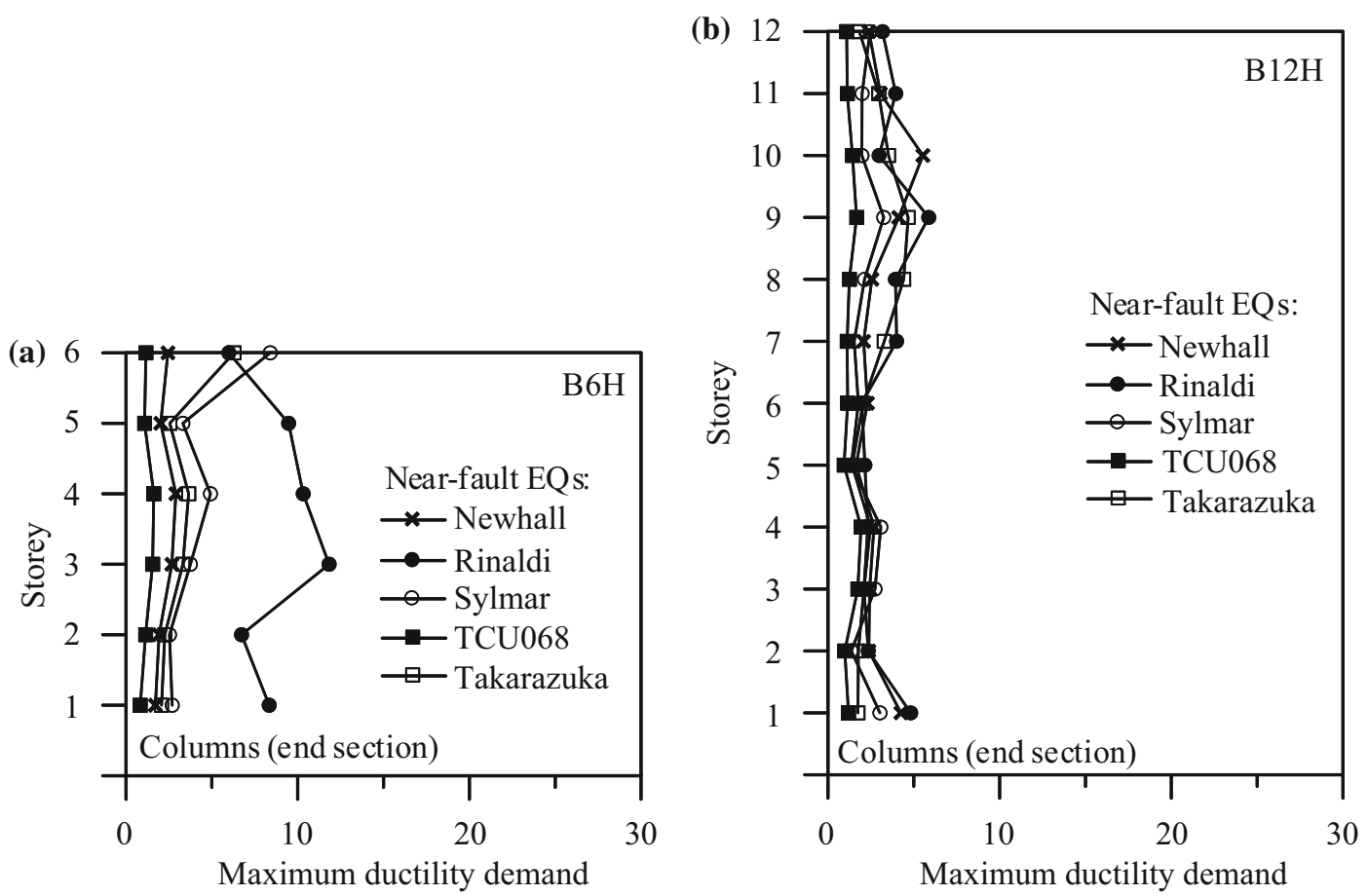

Fig. 14 Maximum ductility demand at the end section of the columns: B6H and B12H structures subjected to near-fault motions exhibiting pulse-type horizontal components
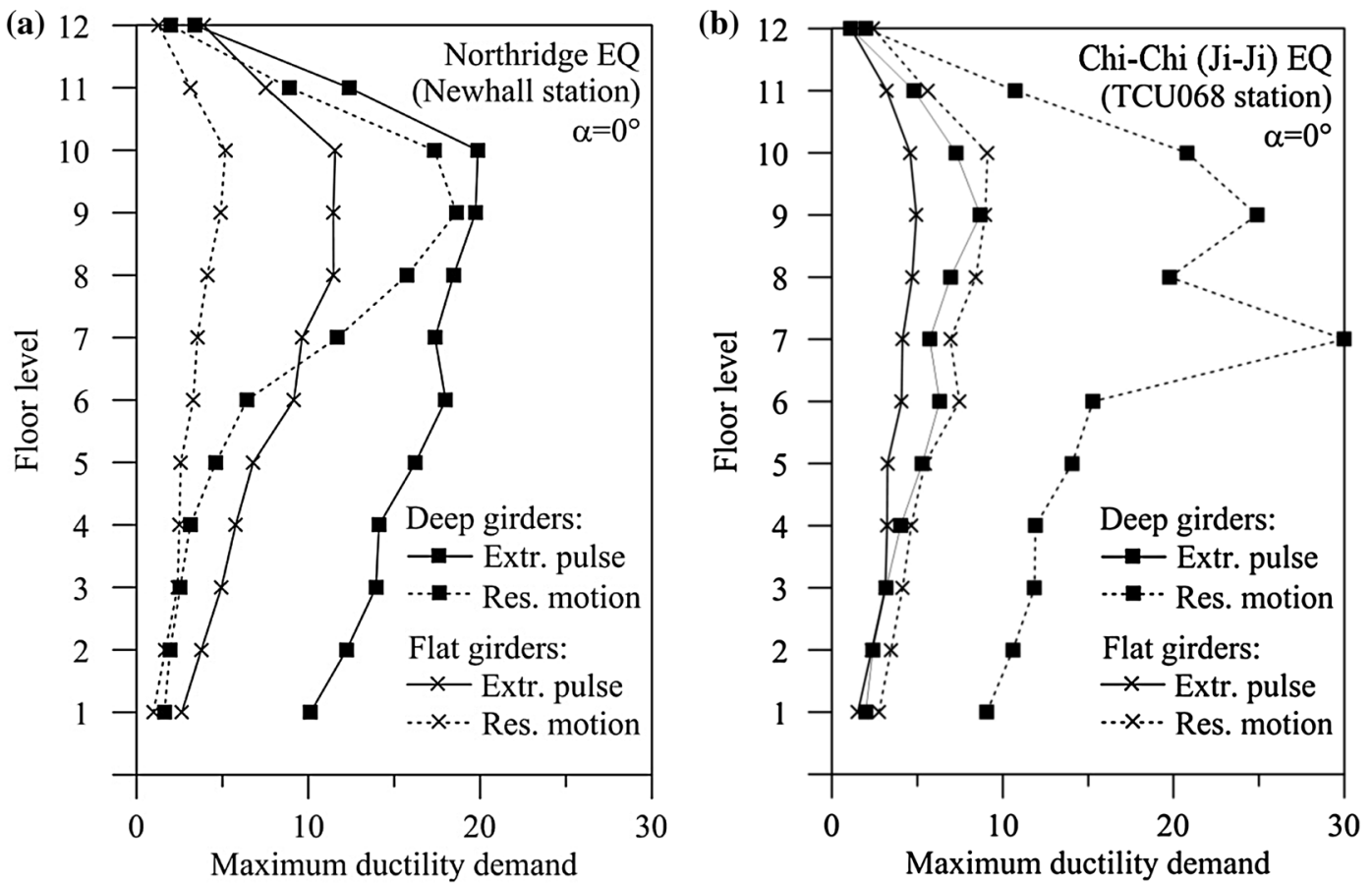

Fig. 15 Maximum ductility demand of the girders: B12H structure subjected to the horizontal components of the extracted pulse and residual motion of the Northridge EQ and Chi-Chi (Ji-Ji) EQs 

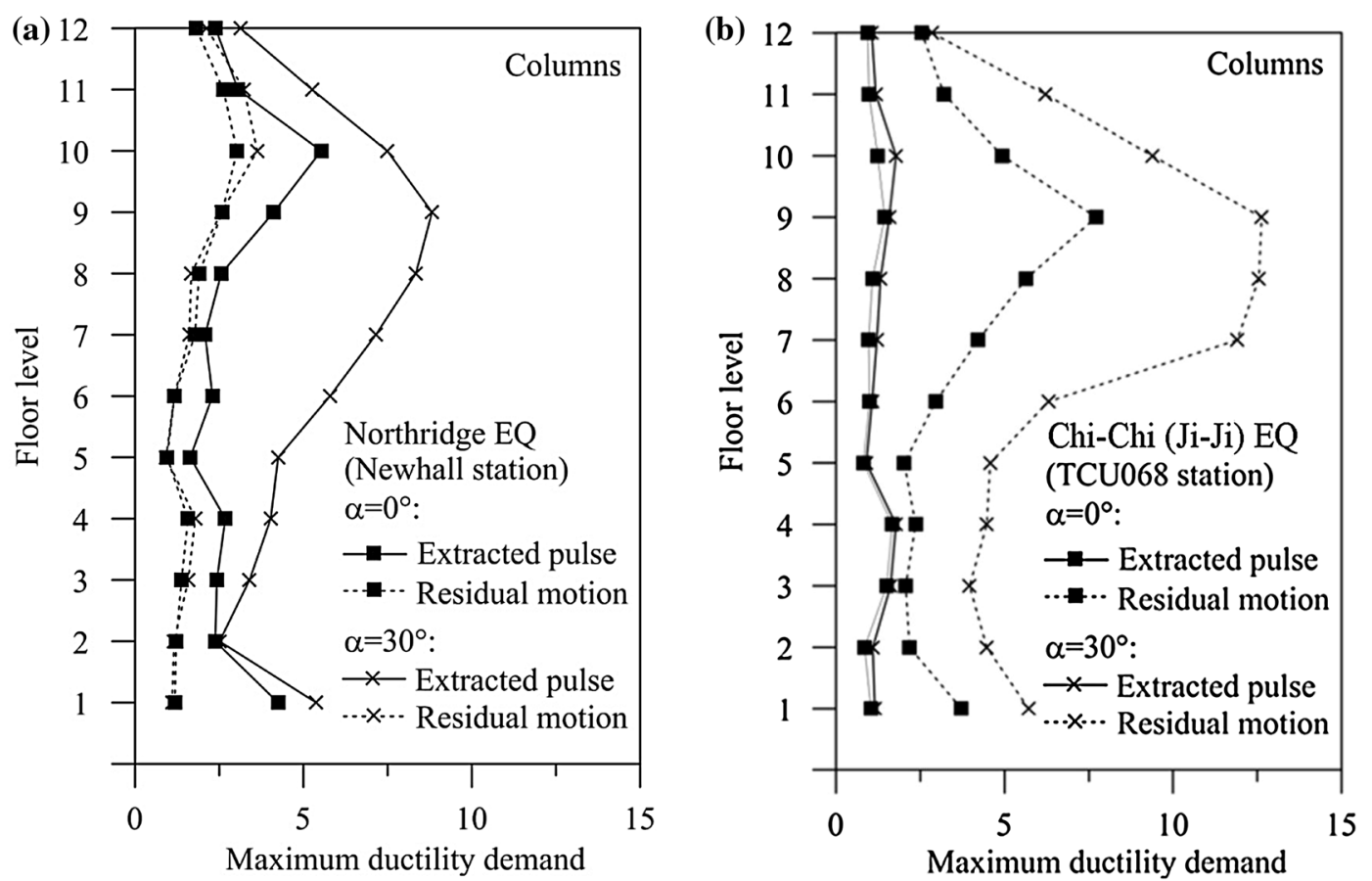

Fig. 16 Maximum ductility demand of the columns: B12H structure subjected to the horizontal components of the extracted pulse and residual motion of the Northridge and Chi-Chi (Ji-Ji) EQs. a Deep and flat girders. b Columns

\section{Conclusions}

A nonlinear beam model, representing a good compromise between accuracy and computational efficiency, has been considered for the seismic analysis of r.c. spatial frames. An enhanced LPM has been adopted to model the inelastic behaviour of r.c. spatial frames subjected to near-fault ground motions characterized by high values of the acceleration ratio $\alpha_{\text {PGA }}$. Axial load-biaxial bending moment elastic domain is considered for the columns. In order to emphasize the importance of also taking into account the vertical component of near-fault ground motions, three intermediate sections of control of the girders (i.e. the two quarter-span sections and the mid-span section) are checked in addition to the end sections. However, each girder is discretized with only one element instead of four sub-elements, reducing the computational effort.

The nonlinear seismic response of six- and twelve-storey r.c. framed buildings, designed considering (besides the gravity loads) the horizontal seismic loads acting alone or in combination with the vertical seismic loads, was studied under the horizontal and vertical components of near-fault ground motions. In particular, five earthquakes are selected among those exhibiting high values of the acceleration ratio $\alpha_{\mathrm{PGA}}$ and other five earthquakes exhibiting pulse-type horizontal components identified using a pulse indicator, depending on the original ground motion and the residual motion after the pulse extraction. The vertical component of near-fault ground motions affected the ductility demand in the end sections and quarter-span sections of deep girders, especially at the upper storeys, also for the structure designed considering vertical seismic loads. Flat girders are practically independent of the vertical component due to their small tributary mass. As regards the columns, the addition of the vertical motion induced a large variation in the axial force, producing even tension and high compressive forces (larger than the balanced force), which are more evident at the lower storeys. Finally the pulse-type nature of the horizontal components of near-fault ground motions affected the ductility demand in the end sections of deep and flat girders and the axial force in the corner columns. The damage due to the extracted pulse proved to be not always greater than that due to the original ground motion. As can be observed, the maximum values occurred at arbitrary fault orientations rather than assuming fault-normal and fault-parallel components along the principal axes of the building plan.

The detailing and design rules of NTC08 gave rise to a significant overstrengthening with regard to the nominal values of the behaviour factor in the horizontal and vertical directions. In all the examined cases, NTC08 capacity design criterion prevented the formation of a soft storey mechanism and a "strong-column weak-beam" mechanism was substantially achieved under the horizontal and 
vertical components of the selected near-fault ground motions. However, the results presented in this paper highlighted that the effects of near-fault ground motions should be taken into account through suitable additional code provisions. Moreover, NTC08 design response spectra take into account the effects of far-fault ground motions, but for r.c. framed buildings, located at less than $15 \mathrm{~km}$ from a known seismic source, site-specific response spectra should be considered. To draw any firm conclusion and propose suitable design rules which take into account the effects of the horizontal and vertical components of near-fault ground motions, further studies are needed also considering arbitrary fault orientations with respect to the building plan.

Open Access This article is distributed under the terms of the Creative Commons Attribution 4.0 International License (http://creativecommons.org/licenses/by/4.0/), which permits unrestricted use, distribution, and reproduction in any medium, provided you give appropriate credit to the original author(s) and the source, provide a link to the Creative Commons license, and indicate if changes were made.

\section{References}

Alaghebandian R, Otani S, Shiohara H (2000) Effect of distributed mass on earthquake response of reinforced concrete frames. In: Proceedings of the 12th World Conference on Earthquake Engineering. Auckland, New Zealand, CD-ROM, paper No. 2230

Alavi B, Krawinkler H (2004) Behavior of moment-resisting frame structures subjected to near-fault ground motions. Earthq Eng Struct Dynam 33:687-706

Anderson JC, Bertero VV (1987) Uncertainties in establishing design earthquakes. J Struct Eng 113(8):1709-1725

Baker JW (2007) Quantitative classification of near-fault ground motions using wavelet analysis. Bull Seismol Soc Am 97(5):1486-1501. doi:10.1785/0120060255

Baratta A, Corbi I, Corbi O, Barros RC, Bairrão R (2012) Shaking table experimental researches aimed at the protection of structures subject to dynamic loading. Open Constr Build Technol J 6:355-360

Bozorgnia YM, Campbell KW (2004) The vertical to horizontal response spectral ratio and tentative procedures for developing simplified $\mathrm{V} / \mathrm{H}$ and vertical design spectra. J Earthq Eng 8:175-207

Chioccarelli E, Iervolino I (2010) Near-source seismic demand and pulse-like records: a discussion for L'Aquila earthquake. Earthq Eng Struct Dynam 39:1039-1062

Decanini LD, Liberatore L, Mollaioli F (2002) Response of bare and infilled $\mathrm{rc}$ frames under the effect of horizontal and vertical seismic excitation. In: Proceedings of the 12th European Conference on Earthquake Engineering, London, U.K., CDROM, paper No. 164

Elnashai AS, Papazoglou AJ (1997) Procedure and spectra for analysis of rc structures subjected to strong vertical earthquake loads. J Earthq Eng 1(1):121-156

Eurocode 8 (2003) Design of structures for earthquake resistancepart 1: general rules, seismic actions and rules for buildings, UNI ENV 1998-1
Hall JF, Heaton TH, Halling MW, Wald DJ (1995) Near-source ground motion and its effects on flexible buildings. Earthq Spectra 11(4):569-605

Kim SJ, Elnashai AS (2008) Seismic assessment of rc structures considering vertical ground motion. University of Illinois at Urbana-Champaign, USA, MAE Center Report No. 08-03

Kunnath SK, Erduran E, Chai YH, Yashinsky M (2008) Effect of near-fault vertical ground motions on seismic response of highway overcrossings. J Bridge Eng 13(3):282-290

Li S, Xie LL (2007) Progress and trend on near-field problems in civil engineering. Acta Seismol Sin 20(1):105-114

Liao W-I, Loh C-H, Wan S (2001) Earthquake responses of RC moment frames subjected to near-fault ground motions. Struct Design Tall Spec Build 10(3):219-229

MacRae GA, Morrow DV, Roeder CW (2001) Near-fault ground motion effects on simple structures. J Struct Eng 127(9):9961004

Mazza F (2014a) distributed plasticity model to simulate the biaxial behaviour in the nonlinear analysis of spatial framed structures. Comput Struct 135:141-154

Mazza F (2014b) Displacement-based seismic design of hysteretic damped braces for retrofitting in-plan irregular r.c. framed structures. Soil Dynam Earthq Eng 66:231-240

Mazza F (2014c) Modeling and nonlinear static analysis of reinforced concrete framed buildings irregular in plan. Eng Struct 80: 98-108

Mazza F (2015a) Nonlinear incremental analysis of fire-damaged r.c. base-isolated structures subjected to near-fault ground motions. Soil Dynam Earthq Eng 77:192-202

Mazza F (2015b) Comparative study of the seismic response of RC framed buildings retrifitted using modern techniques. Earthq Struct 9(1):29-48

Mazza F, Mazza M (2010) Nonlinear analysis of spatial framed structures by a lumped plasticity model based on the HaarKàrmàn principle. Comput Mech 45:647-664

Mazza F, Vulcano A (2009) Nonlinear response of RC framed buildings with isolation and supplemental damping at the base subjected to near-fault earthquakes. J Earthq Eng 13(5):690-715

Mazza F, Vulcano A (2010) Nonlinear dynamic response of r.c. framed structures subjected to near-fault ground motions. Bull Earthq Eng 8(6):1331-1350

Mazza F, Vulcano A (2011) Control of the earthquake and wind dynamic response of steel-framed buildings by using additional braces and/or viscoelastic dampers. Earthq Eng Struct Dynam 40(2):155-174

Mazza F, Vulcano A (2013) Nonlinear seismic analysis to evaluate the effectiveness of damped braces. Int J Mech 7(3):251-261

Mazza F, Vulcano A (2014a) Equivalent viscous damping for displacement-based seismic design of hysteretic damped braces for retrofitting framed buildings. Bull Earthq Eng 12(6): $2797-2819$

Mazza F, Vulcano A (2014b) Design of hysteretic damped braces to improve the seismic performance of steel and $\mathrm{RC}$ framed structures. Ingegneria Sismica 31(1):1-12

Mazza F, Vulcano A (2014c) Displacement-based design procedure of damped braces for the seismic retrofitting of r.c. framed buildings. Bull Earthq Eng 13(7):2121-2143

Mazza F, Mazza M, Vulcano A (2012) Nonlinear dynamic response of R.C. buildings with different base-isolation systems subjected to horizontal and vertical components of near-fault ground motions. Open Constr Build Technol J 6:373-383

Mazza F, Mazza M, Vulcano A (2015) Displacement-based seismic design of hysteretic damped braces for retrofitting in-elevation irregular r.c. framed structures. Soil Dynam Earthq Eng 69:115124 
Next Generation Attenuation (NGA) database (2008) Pacific Earthquake Engineering Research center. http://peer.berkeley.edu/ peer_ground_motion_database

NTC08 (2008) Technical regulations for the constructions. Italian Ministry of the Infrastructures (in Italian)

Papazoglou AJ, Elnashai AS (1996) Analytical and field evidence of the damaging effect of vertical earthquake ground motion. Earthq Eng Struct Dynam 25:1109-1137

Perea T, Esteva L (2004) Analysis of vertical ground motions of nearsource records in Mexico. In: Proceedings of the 13th World Conference on Earthquake Engineering, Vancouver, Canada, CD-ROM, paper No. 1852
Ponzo FC, Di Cesare A, Nigro D, Vulcano A, Mazza F, Dolce M, Moroni C (2012) Jet-pacs project: Dynamic experimental tests and numerical results obtained for a steel frame equipped with hysteretic damped chevron braces. J Earthq Eng 16(5):662-685

Sorace S, Terenzi G (2014) A viable base isolation strategy for the advanced seismic retrofit of an R/C building. Contemp Eng Sci 7(17-20):817-834

Tirca L-D, Foti D, Diaferio M (2003) Response of middle rise steel frames with and without passive dampers to near-field ground motions. Eng Struct 25(2):169-179 